In cooperation with the Menominee Indian Tribe of Wisconsin

\title{
Simulation of the Regional Groundwater-Flow System of the Menominee Indian Reservation, Wisconsin
}

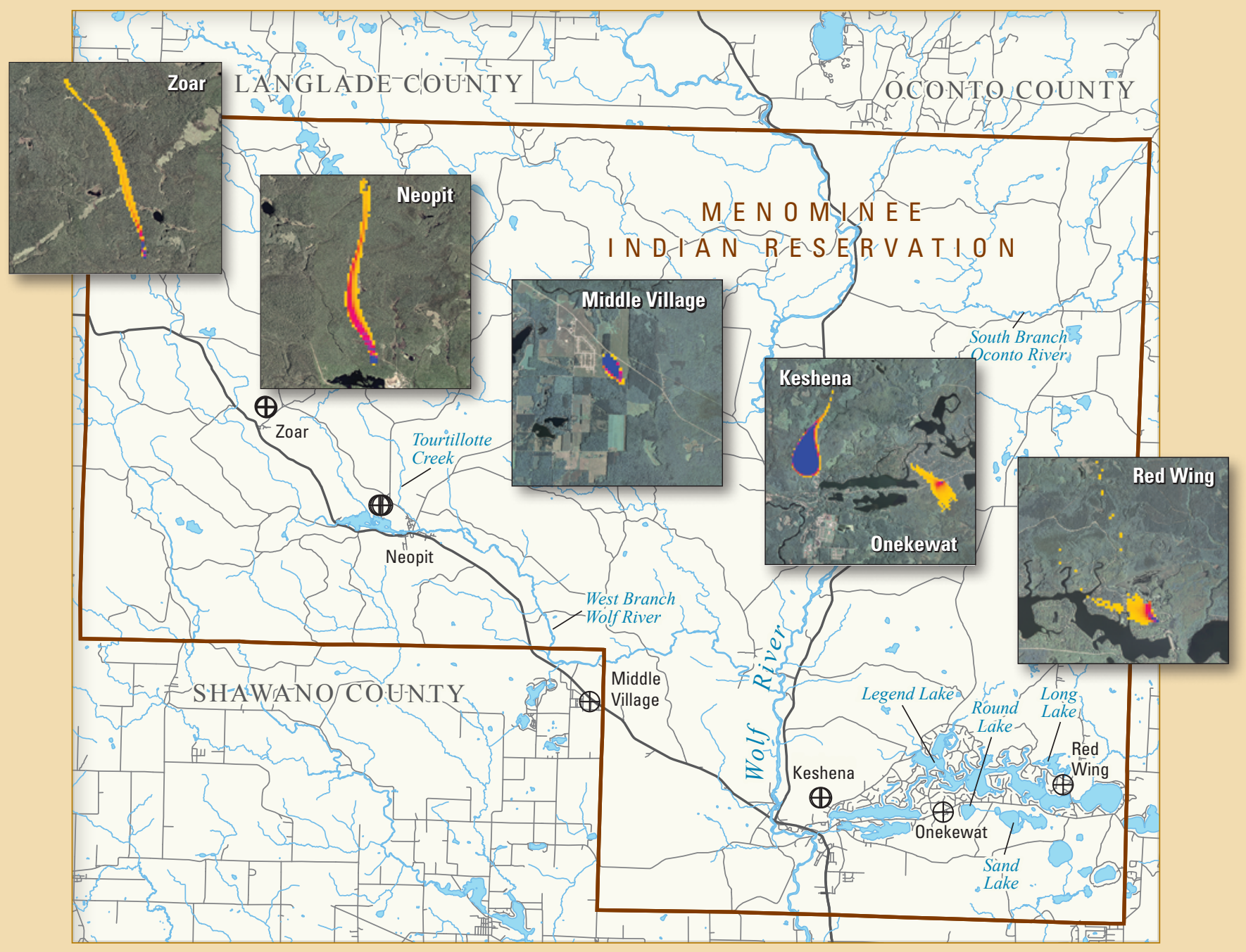

Scientific Investigations Report 2014-5237 
Cover image. Map of the Menominee Indian Reservation with inset maps showing the probabilistic contributing areas to production wells. 


\section{Simulation of the Regional Groundwater-Flow System of the Menominee Indian Reservation, Wisconsin}

By Paul F. Juckem and Charles P. Dunning

In cooperation with the Menominee Indian Tribe of Wisconsin

Scientific Investigations Report 2014-5237 


\title{
U.S. Department of the Interior SALLY JEWELL, Secretary
}

\section{U.S. Geological Survey Suzette M. Kimball, Acting Director}

\author{
U.S. Geological Survey, Reston, Virginia: 2015
}

For more information on the USGS - the Federal source for science about the Earth, its natural and living resources, natural hazards, and the environment, visit http://www.usgs.gov or call 1-888-ASK-USGS.

For an overview of USGS information products, including maps, imagery, and publications, visit http://www.usgs.gov/ pubprod

To order this and other USGS information products, visit http://store.usgs.gov

Any use of trade, firm, or product names is for descriptive purposes only and does not imply endorsement by the U.S. Government.

Although this information product, for the most part, is in the public domain, it also may contain copyrighted materials as noted in the text. Permission to reproduce copyrighted items must be secured from the copyright owner.

Suggested citation:

Juckem, P.F., and Dunning, C.P., 2015, Simulation of the regional groundwater-flow system of the Menominee Indian Reservation, Wisconsin: U.S. Geological Survey Scientific Investigations Report 2014-5237, 40 p., http://dx.doi.org/10.3133/sir20145237.

ISSN 2328-0328 (online) 


\section{Contents}

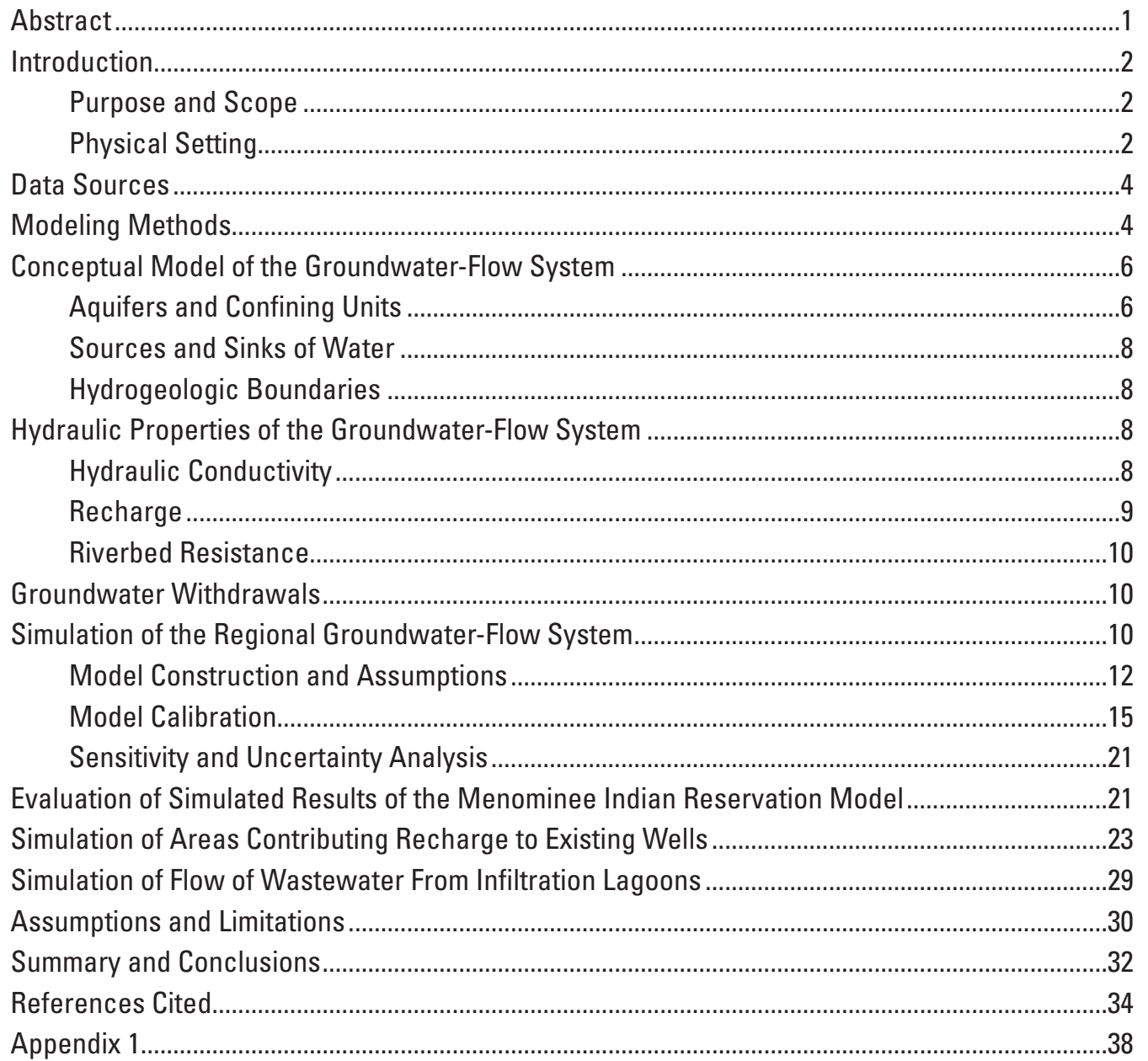

\section{Figures}

1. Map showing hydrologic features of the Menominee Indian

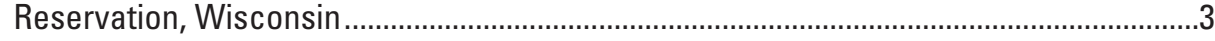

2. Map showing the distribution of glacial deposits in the Menominee Indian Reservation, Wisconsin,

3. Representations of the groundwater-flow system of the Menominee Indian Reservation, Wisconsin.

4. Map showing hydrologic features and base elevation and hydraulic-conductivity zones simulated with analytic elements, Menominee Indian Reservation, Wisconsin

5. Graph showing simulated water levels in relation to target water levels, Menominee Indian Reservation, Wisconsin

6. Graph showing simulated base flow and gains in base flow in relation to target base flow and gains in base flow, Menominee Indian Reservation, Wisconsin 


\section{Figures (continued)}

7. Map showing water-level- and base-flow-target residuals for the groundwater-flow model of the Menominee Indian Reservation, Wisconsin .20

8. Map showing simulated groundwater-flow directions and water-table contours, Menominee Indian Reservation, Wisconsin

9. Map showing simulated water-table contours and the area contributing recharge to production wells for the village of Zoar, Menominee Indian Reservation, Wisconsin.

10. Map showing simulated water-table contours and the area contributing recharge to production wells for the village of Neopit, Menominee Indian Reservation, Wisconsin.

11. Map showing simulated water-table contours and the area contributing recharge to the production well for Middle Village, Menominee Indian Reservation, Wisconsin

12. Map showing simulated water-table contours and the area contributing recharge to production wells for the villages of Keshena and Onekewat, Menominee Indian Reservation, Wisconsin

13. Map showing simulated water-table contours and the area contributing recharge to production wells for the village of Redwing,

Menominee Indian Reservation, Wisconsin

14. Map showing showing simulated probability of the horizontal plume extent from the Neopit wastewater-treatment lagoons under current (2013) conditions, Menominee Indian Reservation, Wisconsin

\section{Tables}

1. Pumping-test data and TGUESS calculations for production wells near Zoar, Menominee Indian Reservation, Wisconsin.

2. Groundwater withdrawal rates for production wells simulated in the groundwaterflow model of the Menominee Indian Reservation, Wisconsin

3. Calibrated and specified parameter values and composite sensitivities for the groundwater-flow model of the Menominee Indian Reservation, Wisconsin

4. Calibrated hydraulic-conductivity parameters and associated base elevations used to calculate effective hydraulic-conductivity estimates for the Menominee Indian Reservation, Wisconsin.

5. Adjusted porosity estimates used to simulate time-dependent areas contributing recharge for pumped wells, Menominee Indian Reservation, Wisconsin.

6A. Calibration-target descriptions and results for groundwater and lake-level targets, and associated weights used for calibration with the parameter estimation program PEST

$6 B$. Calibration-target descriptions and results for stream base flow and base-flow gain targets, and associated weights used for calibration with the parameter estimation program PEST 


\section{Conversion Factors}

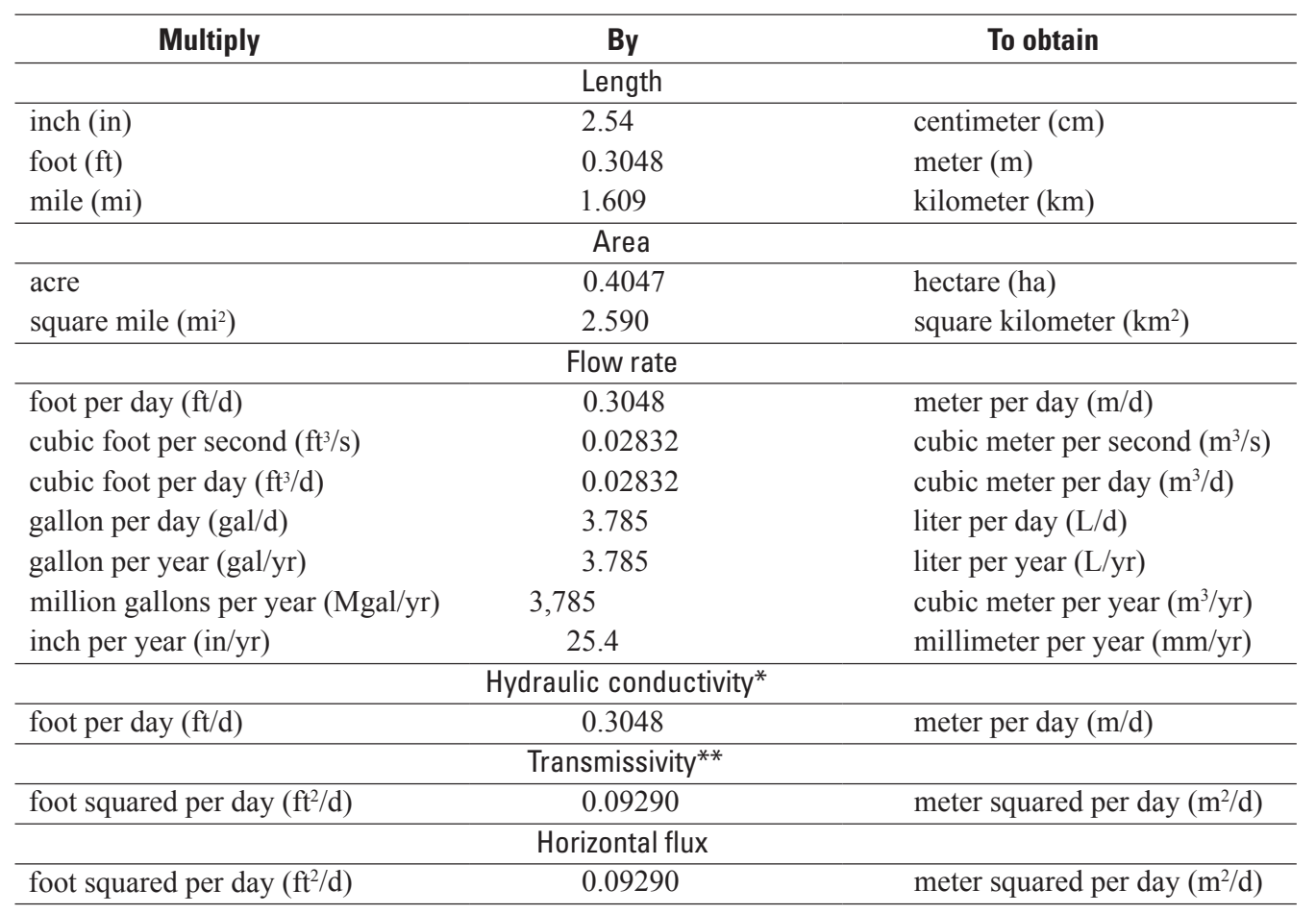

Temperature in degrees Fahrenheit $\left({ }^{\circ} \mathrm{F}\right)$ may be converted to degrees Celsius $\left({ }^{\circ} \mathrm{C}\right)$ as follows:

${ }^{\circ} \mathrm{C}=\left({ }^{\circ} \mathrm{F}-32\right) / 1.8$

Vertical coordinate information is referenced to the North American Vertical Datum of 1988 (NAVD 88).

Horizontal coordinate information is referenced to the North American Datum of 1983 (NAD 83) and the North American Datum of 1927.

Elevation, as used in this report, refers to distance above the vertical datum.

*Hydraulic conductivity: The standard unit for hydraulic conductivity is cubic foot per day per square foot of aquifer cross-sectional area $\left(\mathrm{ft}^{3} / \mathrm{d} / \mathrm{ft}^{2}\right)$. In this report, the mathematically reduced form, foot per day $(\mathrm{ft} / \mathrm{d})$, is used for convenience.

**Transmissivity: The standard unit for transmissivity is cubic foot per day per square foot times foot of aquifer thickness $\left[\left(\mathrm{ft}^{3} / \mathrm{d}\right) / \mathrm{ft}^{2}\right] \mathrm{ft}$. In this report, the mathematically reduced form, foot squared per day $\left(\mathrm{ft}^{2} / \mathrm{d}\right)$, is used for convenience. 


\section{Acknowledgments}

\section{Local Project Coordinators}

Gary Schuettpelz, Former Environmental Services Director, Menominee Indian Tribe of Wisconsin, Keshena, Wisconsin (Wis.)

Jennifer Hill-Kelley, Former Environmental Services Director, Menominee Indian Tribe of Wisconsin, Keshena, Wis.

Kevin Staus, Field Engineer, Indian Health Service, Rhinelander, Wis.

\section{Field and Model Development Support}

Leah Kammel, Hydrologist, U.S. Geological Survey Wisconsin Water Science Center, Middleton, Wis.

Greg Mueller, Former Hydrologist, U.S. Geological Survey Wisconsin Water Science Center, Middleton, Wis.

James Rauman, Hydrologic Technician, U.S. Geological Survey Wisconsin Water Science Center, Middleton, Wis.

Jason Smith, Hydrologic Technician, U.S. Geological Survey Wisconsin Water Science Center, Middleton, Wis.

\section{Publishing Support}

Michelle Greenwood, Reports Specialist, U.S. Geological Survey Wisconsin Water Science Center, Middleton, Wis.

\section{Technical Reviewers}

Christopher Hoard, Hydrologist, U.S. Geological Survey Michigan Water Science Center, Lansing, Michigan.

James Stark, Director, U.S. Geological Survey Minnesota Water Science Center, Mounds View, Minnesota.

\section{Editor}

Mike Eberle, Technical Writer-Editor, U.S. Geological Survey Columbus Publishing Service Center, Columbus, Ohio

\section{Groundwater Specialist Reviewer}

Rodney Sheets, Groundwater Specialist, U.S. Geological Survey, Columbus, Ohio

\section{Approving Official}

Kevin Breen, Bureau Approving Official, U.S. Geological Survey Office of Science Quality and Integrity, New Cumberland, Pennsylvania. 


\title{
Simulation of the Regional Groundwater-Flow System of the Menominee Indian Reservation, Wisconsin
}

\author{
By Paul F. Juckem and Charles P. Dunning
}

\section{Abstract}

A regional, two-dimensional, steady-state groundwaterflow model was developed to simulate the groundwater-flow system and groundwater/surface-water interactions within the Menominee Indian Reservation. The model was developed by the U.S. Geological Survey (USGS), in cooperation with the Menominee Indian Tribe of Wisconsin, to contribute to the fundamental understanding of the region's hydrogeology. The objectives of the regional model were to improve understanding of the groundwater-flow system, including groundwater/ surface-water interactions, and to develop a tool suitable for evaluating the effects of potential regional water-management programs. The computer code GFLOW was used because of the ease with which the model can simulate groundwater/ surface-water interactions, provide a framework for simulating regional groundwater-flow systems, and be refined in a stepwise fashion to incorporate new data and simulate groundwater-flow patterns at multiple scales. Simulations made with the regional model reproduce groundwater levels and stream base flows representative of recent conditions (1970-2013) and illustrate groundwater-flow patterns with maps of (1) the simulated water table and groundwater-flow directions, (2) probabilistic areas contributing recharge to high-capacity pumped wells, and (3) estimation of the extent of infiltrated wastewater from treatment lagoons.

The groundwater-flow model described in this report simulates the major hydrogeologic features of the modeled area, including surficial unconsolidated aquifers, groundwater/ surface-water interactions, and groundwater withdrawals from existing high-capacity production wells. Areas contributing recharge to pumped high-capacity wells on the Menominee Indian Reservation were delineated by tracking simulated water particles from the water table to wells in combination with Monte Carlo techniques, and maps of the probability of capture for each well nest were produced. Groundwater-agebased areas contributing recharge to wells were simulated by using the calibrated set of parameters and porosity values adjusted to account for bias in simulated saturated thickness. Simulations were performed for current (2013) pumping rates.
The simulations show a range in sensitivity of the simulated areas contributing recharge to wells given the parameters evaluated through the Monte Carlo analysis. The areas contributing recharge to supply wells for the villages of Zoar and Neopit are long and narrow, with a sharp gradation from high to low probability of capture. The areas contributing recharge to supply wells for Middle Village and the village of Keshena exhibit a sharp gradation from high to low probability over a relatively small area between the well and a local groundwater mound. The highest probability areas contributing recharge to the supply wells for the Villages of Onekewat and Redwing are in the immediate vicinity of the wells. These wells also have an extensive area with low probability for capturing water that is likely due to a locally low hydraulic gradient and the large degree of uncertainty associated with the lakebed resistance parameters that control interaction between groundwater and local lakes. Additional field investigations and associated local model refinements would facilitate further reductions in uncertainty associated with simulated areas contributing recharge to the wells.

The likely extent of the Neopit wastewater plume was simulated by using the groundwater-flow model and Monte Carlo techniques to evaluate the sensitivity of predictive simulations to a range of model parameter values. Wastewater infiltrated from the currently operating lagoons flows predominantly south toward Tourtillotte Creek. Some of the infiltrated wastewater is simulated as having a low probability of flowing beneath Tourtillotte Creek to the nearby West Branch Wolf River. Results for the probable extent of the wastewater plume are considered to be qualitative because the method only considers advective flow and does not account for processes affecting contaminant transport in porous media. Therefore, results for the probable extent of the wastewater plume are sensitive to the number of particles used to represent flow from the lagoon and the resolution of a synthetic grid used for the analysis. Nonetheless, it is expected that the qualitative results may be of use for identifying potential downgradient areas of concern that can then be evaluated using the quantitative "area contributing recharge to wells" method or traditional contaminant-transport simulations. 


\section{Introduction}

A primary objective for resource managers of the Menominee Indian Reservation (fig. 1) is sustainable management of water resources (http://www.menominee-nsn. gov/MITW/DepartmentDetails.aspx?departmentID=2100, accessed November 3, 2013). Though both surface-water and groundwater resources are generally plentiful, most domestic and municipal needs are provided by groundwater. Several local-scale drilling investigations (described under the heading "Data Sources") were completed over a nearly 10-year period on the Menominee Indian Reservation, each targeting specific areas and resource issues. This report describes the data collected as part of those investigations and subsequent reservationwide groundwater-flow simulations.

The study described in this report was conducted by the U.S. Geological Survey (USGS) in cooperation with the Menominee Tribe of Wisconsin. The objectives of the study were to improve understanding of the hydrogeology of the Menominee Indian Reservation, estimate areas contributing recharge to pumped high-capacity production wells, and provide a tool for effective management of surface-water and groundwater resources. These objectives were achieved by developing a computer model using the program GFLOW to simulate the groundwater-flow system of the reservation. This computer model embodies the regional characteristics of the groundwater-flow system and includes additional hydrogeologic detail in areas of particular interest to answer local-scale questions. This model is a tool that can be used to improve the overall understanding of the hydrology of a region by testing alternative conceptual models of the groundwater-flow system. Additionally, this model can be used to identify areas where more hydrogeological or water-quality data are needed to address a specific question. Finally, this model serves as a foundation from which future local or site-specific models can be developed. The benefits of having this foundation include reducing construction time of future local-scale models in the area, reducing data-collection and interpretation efforts, and providing a simulated connection to the regional flow system.

On the Menominee Indian Reservation, the groundwater and surface-water systems are believed to be hydraulically well connected, and as a result the groundwater-flow model has been constructed to include many aspects of the surfacewater network. The simulation of groundwater flow and its interaction with the surface-water network is a necessary foundation for understanding and protecting the water resources of the reservation. By improving the understanding of the hydrology of the Menominee Indian Reservation, this study provides a basis for interpreting previously collected water-quality data and managing water resources for the future.

The hydrogeologic framework of the Menominee Indian Reservation model draws from previous geologic and hydrologic studies. The bedrock geology of Wisconsin was mapped by Mudrey and others (1982), with a subsequent digital representation by Cannon and others (1997). Other reports present descriptions of the soil and unconsolidated glacial deposits of the area (Milfred and others, 1967; Hadley and Pelham, 1976; Farrand and others, 1984; Mickelson, 1986; Attig and Ham, 1999; Hooyer and Mode, 2007). The general hydrology of the region is described in two USGS Hydrologic Investigations Atlases (Olcott, 1968; Oakes and Hamilton, 1973). Krohelski and others (1994) describe water resources within the Menominee Indian Reservation.

\section{Purpose and Scope}

The purpose of this report is to describe the hydrogeology of the Menominee Indian Reservation and the development and applications of a computer model that simulates regional groundwater flow for the reservation. Geological and hydrological data used for this study consisted of previously published reports and interpretive maps, historical streamflow and water-level measurements, and hydrological and physical data collected during recent years by scientists of the USGS and Menominee Tribe. The report includes a summary of selected hydrogeological data, conceptualization of the hydrogeologic setting of the reservation, and details on the construction and calibration of a one-layer, steady-state, analytic element model that simulates groundwater flow and its interaction with surface-water features at a regional scale. The purpose of the model is to simulate regional groundwater-flow patterns, delineate areas contributing recharge to pumped wells, and estimate the extent of wastewater infiltration from a wastewater-treatment lagoon. Results of simulations conducted with the calibrated analytic element model are presented with maps and associated descriptions that illustrate (1) groundwaterflow directions, (2) areas contributing recharge to pumped high-capacity wells, and (3) the flow of infiltrated water from a wastewater-treatment lagoon.

\section{Physical Setting}

The Menominee Indian Reservation is in northeastern Wisconsin, and the reservation boundaries approximate those of Menominee County, except near Middle Village, which is in Shawano County. The reservation encompasses a hydrologically complex landscape of approximately 360 square miles $\left(\mathrm{mi}^{2}\right)(230,400$ acres$)$ containing numerous rivers, lakes, and wetlands (fig. 1). The Wolf River flows from north to south through the reservation and, with its tributaries, drains most of the reservation. The eastern part of the reservation is drained by the South Branch of the Oconto River as it flows eastward into Oconto County. Another important hydrological feature is the area of lakes east of Keshena, which includes the largest of the 44 lakes on the reservation-Legend Lake (1,304 acres). The majority of the other lakes (32) on the reservation are less than 50 acres in size; the smallest named lake is Red Springs Lake (1 acre).

The Menominee Indian Reservation is in part of two different physiographic regions of Wisconsin (Martin, 1965). The northwestern two-thirds is in the Northern Highlands 


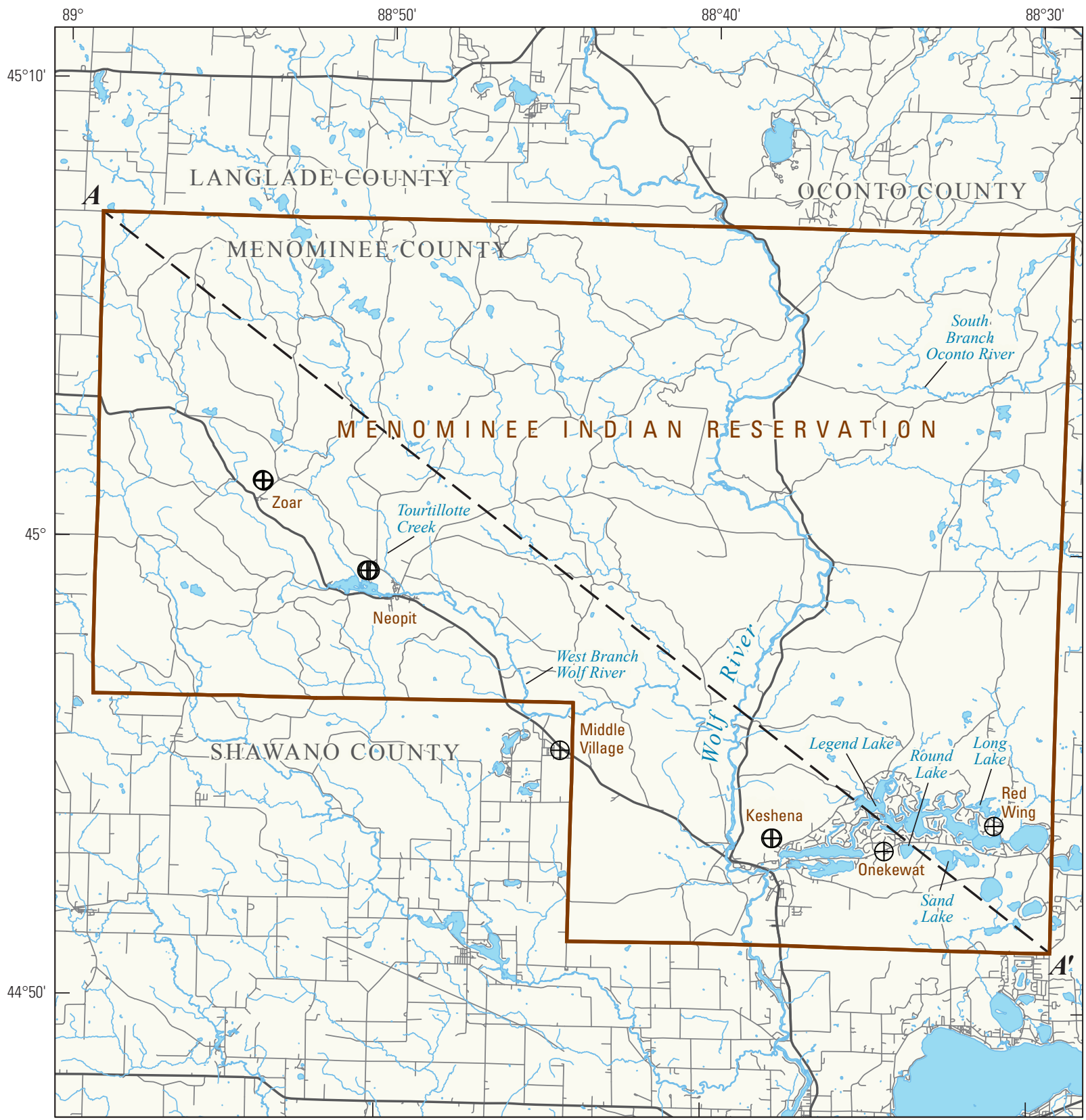

Base map from U.S. Census Bureau, 2013, and Wisconsin Department of Natural Resources, 2009

EXPLANATION

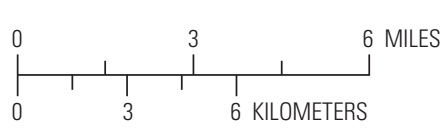

Menominee Indian Reservation

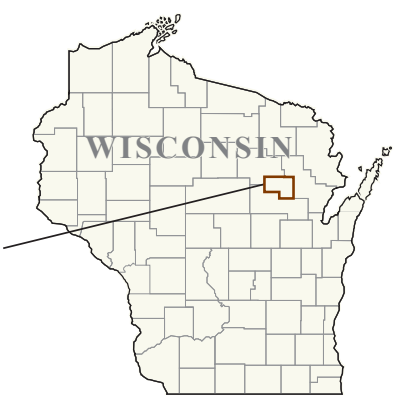

Reservation boundary

Lake or pond

River or stream

State highways

County and town roads

$A_{-}-$Extent of conceptual model in figure 3

$\bigoplus \quad$ Production well

Figure 1. Hydrologic features of the Menominee Indian Reservation, Wisconsin. 
region, which is characterized by mixed glacial till of the most recent glacial epoch. The drainage system in this area is characterized by abundant rapids in the streams along with large undrained interstream areas where lakes and wetlands are common. The southeastern one-third is in the Central Plain region, where glacial deposits are typically sandier. The northeastern part of Wisconsin, which includes the Menominee Indian Reservation, receives about 30 inches (in.) of precipitation annually (Wisconsin State Climatology Office, 2013). Daily high temperatures typically range from an average of around 24 degrees Fahrenheit $\left({ }^{\circ} \mathrm{F}\right)$ in January to an average of around $81^{\circ} \mathrm{F}$ in July (Midwestern Regional Climate Center, 2013). Land cover in the reservation is dominated by roughly 223,500 acres of heavily forested lands (97 percent of total land area), representing the largest single tract of virgin timberland in Wisconsin. The remaining 3 percent of land area consists of developed land and open water (Wisconsin Department of Natural Resources, WISCLAND, 1998).

The Menominee Indian Reservation is underlain by Precambrian crystalline rocks known as the Wolf River Granite (Krohelski and others, 1994). The elevation of the Precambrian crystalline bedrock surface varies by hundreds of feet over the study area as a result of erosion by late Pleistocene glaciers, but in general the surface slopes irregularly to the southeast at about 26 feet per mile. Bedrock elevation is about 1,250 feet (ft) in the northwestern corner of the reservation and decreases to less than $700 \mathrm{ft}$ in the southeastern corner (Krohelski and others, 1994). The crystalline bedrock crops out locally on the reservation but is most often overlain by unconsolidated glacial deposits up to about $200 \mathrm{ft}$ thick. The sediments which compose these deposits were carried by glacial ice and meltwater across most of the reservation area during the Wisconsin glaciation (10,000-25,000 years ago) and are generally pitted outwash and moraine deposits comprised of sand, gravel, and till. The distribution of glacial deposits, soils, and vegetation was mapped by Milfred and others (1967), and an interpretation of the glacial sediments is provided by Farrand and others (1984) (fig. 2).

\section{Data Sources}

Background geologic information used in this study was based primarily upon a Quaternary geologic map of the Lake Superior quadrangle, United States and Canada, by Farrand and others (1984). Supplemental mapping and interpretation were garnered from maps by Milfred and others (1967), Hadley and Pelham (1976), Mickelson (1986), Attig and Ham (1999), and Hooyer and Mode (2007).

Test borings were drilled at three locations between 2001 and 2008 on the Menominee Indian Reservation to gather localized data on depth to bedrock, static water level, and lithology. Borehole investigations were conducted in the vicinity of the villages of Neopit and Zoar from July 9 to July 17, 2001. A similar investigation was conducted in the vicinity of Keshena from August 7 to September 11, 2002. The
Neopit area was revisited for additional borehole investigations from May 29 to July 1, 2008. Data were collected from boreholes augered with either a CME75 drill rig or Geoprobe 66DT. Field operations included the following steps: (1) set up the drill rig or Geoprobe and determine map coordinates by using a handheld GPS unit, (2) auger until bedrock refusal or until all available augers had been added to the auger string, (3) collect and roughly describe the lithology of auger returns (Zoar and Keshena only), (4) temporarily install a monitoring well in the borehole by using a 5 -ft-long slotted screen placed so as to intersect the water table, and (5) measure and record the static water level in the monitoring well upon stabilization. For boreholes in which a monitoring well was not installed, the borehole was permanently abandoned by backfilling with bentonite grout chips to about $5 \mathrm{ft}$ of land surface, followed by emplacement of auger cuttings to the surface. These data increased the understanding of the buried topography of the crystalline bedrock and the thickness and saturated thickness of the unconsolidated aquifer at select locations. Details on these borehole investigations are provided in appendix 1 .

River water-level elevations derived from USGS topographic maps were used for model development and are expected to represent long-term average base-flow conditions to within a few feet. Although water levels on topographic maps represent elevations observed during the mapmaking period, the rivers are assumed to be at a geomorphic steady state in terms of erosion and deposition, with little systematic trend in river base flow water level over time. All surface-water-level measurements are reported as feet and are referenced to the North American Vertical Datum of 1988 (NAVD 88). River flow data consist of gaged and miscellaneous discharge measurements archived in the USGS National Water Inventory System (NWIS) database (Dempster, 1990) and analyzed with methods developed by Gebert and others (2011) to estimate base flows. Groundwater level data were obtained from NWIS, well-construction reports submitted to the Wisconsin Department of Natural Resources (2010), and measurements made during this study (appendix 1).

\section{Modeling Methods}

An analytic element groundwater-flow model was developed to simulate the regional groundwater-flow system and its interaction with surface-water features; the computer program GFLOW (Haitjema, 1995) was used to construct the model. The model simulates groundwater flow by using the Dupuit-Forchheimer approximations, which simplify a threedimensional flow system into a two-dimensional, areal flow system. These approximations are well suited for the Menominee Indian Reservation, where the ratio of horizontal to vertical dimensions of the aquifer is very large (Haitjema, 1995); that is, the Menominee Indian Reservation extends a distance from east to west of about $25 \mathrm{mi}$, or $132,000 \mathrm{ft}$, whereas the total aquifer thickness does not exceed about $200 \mathrm{ft}$. A complete description of analytic element modeling is beyond the 


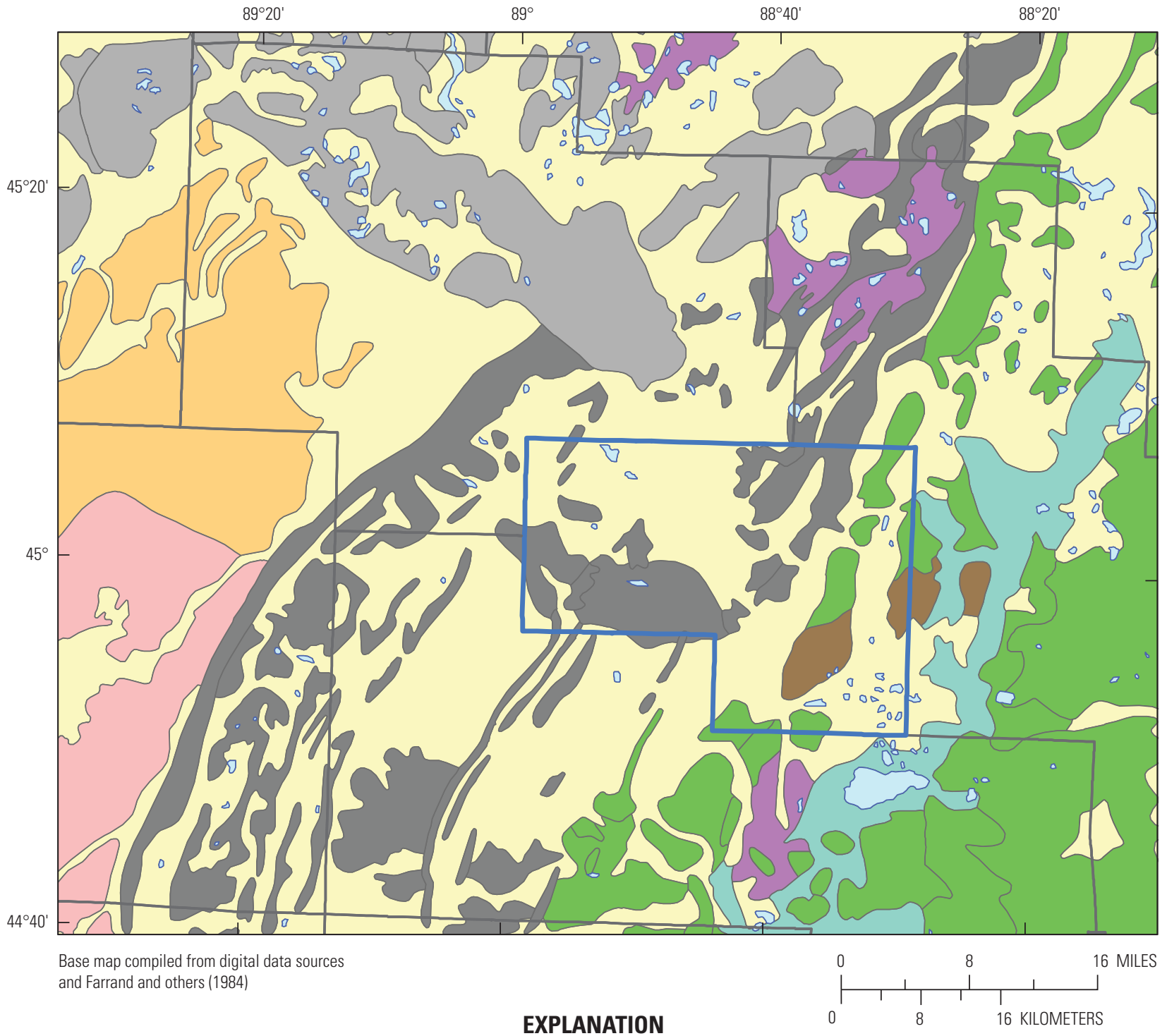

\section{Glacial deposits}

(Lithologic code from Farrand and others, 1984)

\begin{tabular}{|c|l}
\hline gg & Outwash sand and gravel \\
\hline $\mathrm{kg}$ & Ice-contact sand and gravel \\
\hline & Lake (open water) \\
\hline Ica & Lake silt and clay \\
\hline tc & Clayey till \\
\hline td & Calcareous sandy loamy till \\
\hline tdb & Noncalcareous sandy loamy till \\
\hline tde & Sandy loamy till \\
\hline tl & Loamy till \\
\hline tlq & Loamy till (pre-Wisconsinan) \\
\hline
\end{tabular}

Figure 2. The distribution of glacial deposits in the Menominee Indian Reservation, Wisconsin, after Farrand and others (1984). 
scope of this report, but a brief description is provided in the following paragraph. In addition, Hunt (2006) gives a review of applications of the analytic element method, and Haitjema (1995) discusses the underlying concepts and mathematics of the method in detail.

A horizontally infinite aquifer is assumed in analytic element modeling. The problem domain (model area) does not require a grid or involve interpolation between cells as required for finite difference or finite element methods. To construct an analytic element model, the modeler identifies features that are important for controlling groundwater flow (for example, wells, surface-water features, and zones of uniform transmissivity) and represents them in the model as a point element or line element with defined physical properties. The closer a hydrologic feature is to an area of interest, the greater the amount of detail required to adequately simulate that feature. For example, greater detail for a river would result in a linesink string with many individual segments that follow the meandering channel or variations in downstream slope. Analytic elements included in the Menominee Indian Reservation model included specified-discharge wells, linesinks (river), and inhomogeneities (zones of transmissivity). Each analytic element adds an equation to the model, and the effects of these individual features are added together to form a solution for any location in the simulated groundwater-flow system. Because the solution is not confined to a grid, hydraulic heads and hydrologic flows can be computed at any location in the model domain without interpolating between grid cells. In the GFLOW model developed for the Menominee Indian Reservation, the analytic elements are two dimensional and only simulate steady-state conditions (water levels do not vary with time). A primary value of regional-scale analytic element modeling is to identify the hydrological features which are most important in controlling groundwater flow. These features can then be used to better define local conditions, test hypotheses, and answer site-specific questions as specific local data are incorporated into the model. The analytic element method and comparisons of analytic element to finite-difference numerical modeling techniques have been discussed by others (Haitjema, 1995; Hunt and others 1998; and Hunt and others, 2003).

The GFLOW model of the Menominee Indian Reservation was calibrated by means of parameter-estimation techniques. Numerous publications detail the advantages of parameter estimation (for example, Poeter and Hill, 1997; Kelson and others, 2002). Briefly, the primary benefit of a properly prepared and executed parameter-estimation calibration over typical trial-and-error calibration is the ability to automatically calculate parameter values (for example, hydraulic conductivity and recharge) that are a quantified best fit between simulated model output and observed data (typically groundwater level and streamflow data). In addition, parameter sensitivity can be quantified to assess model parameters that have the greatest influence on simulated results. In this study, the GFLOW model was coupled with the parameter estimation code PEST (Doherty, 2012).

\section{Conceptual Model of the Groundwater- Flow System}

Conceptualization of the hydrologic system forms the framework for mathematical model development and simplifies the groundwater system into important components. Simplification of the natural system is necessary because inclusion of all its complexities into a computer model is not feasible given existing knowledge of the subsurface. Steps in the development of the conceptual model are (1) characterization of aquifers and confining units, (2) identification of sources and sinks of water, and (3) identification and delineation of hydrologic boundaries encompassing the area of interest. The first two of these steps were accomplished by review and interpretation of available geologic and hydrogeologic data. The third step was accomplished through the model design (see "Hydrogeologic Boundaries," below). The conceptual model of the groundwater-flow system is shown in figure 3 . The vertical scale of the conceptual model diagram has been greatly exaggerated to illustrate the geologic relationships (fig. $3 A$ ); regional flow through the aquifers is primarily horizontal (fig. 3B).

\section{Aquifers and Confining Units}

The principal aquifer of the Menominee Indian Reservation is composed of laterally extensive unconsolidated glacial deposits, represented generally by pitted outwash and moraine deposits. Outwash deposits are composed of stratified sand and gravel that occur as layers, lenses, terrace deposits, and valley fills that range in thickness across the study area from 0 to $200 \mathrm{ft}$ (Krohelski, and others, 1994). Moraine deposits are primarily composed of poorly sorted tills that incorporate lithologies ranging from clay and silt to sand, gravel, and cobbles, although most tills in the study area are mapped as sandy tills (Hadley and Pelham, 1976; Farrand and others, 1984; Mickelson, 1986; Attig and Ham, 1999; Hooyer and Mode, 2007). Confining units of finer grained glacial till are believed to be only locally important.

The reservation is underlain by crystalline bedrock composed of the Wolf River Granite (Krohelski, and others, 1994). Although the crystalline bedrock can be a productive aquifer and is often included in the completion interval of wells, its hydraulic conductivity is dependent largely on the presence of fractures and is much less than that of the overlying unconsolidated sediments (Krohelski, and others, 1994). Therefore, the highly transmissive glacial sediments are considered to be bounded below by low-transmissivity bedrock in the model. However, where present, fractures in the upper crystalline bedrock may contribute locally to the groundwater resource.

The irregularity of the bedrock surface and the hilly terrain across the Menominee Indian Reservation result in a glacial aquifer with variable depths to groundwater and saturated thickness across the study area (Krohelski, and others, 1994). The glacial aquifer has a saturated thickness ranging 


\section{A. Idealized cross section}

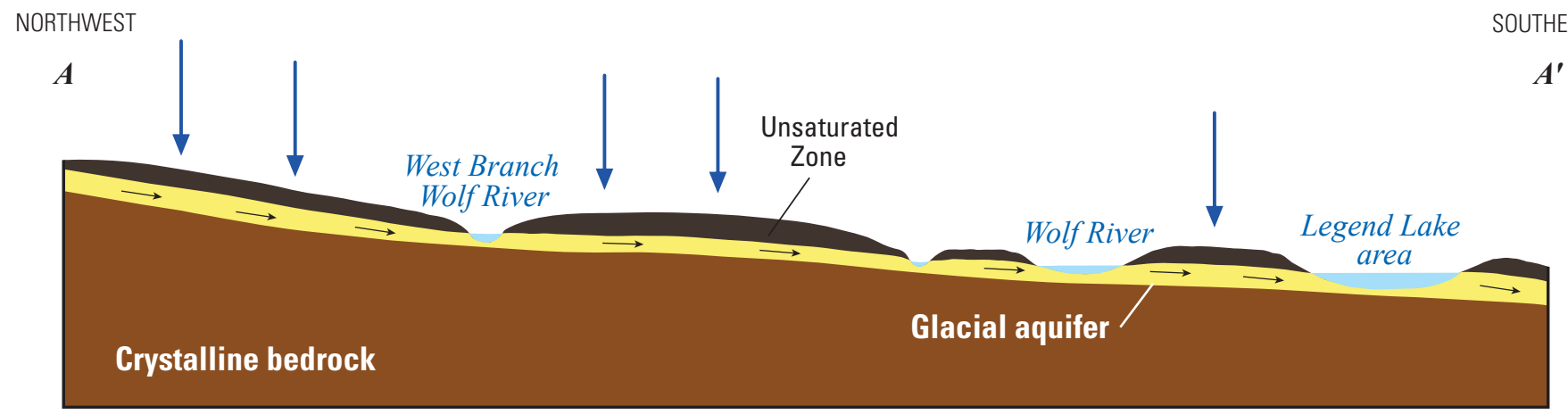

Vertical dimension is greatly exaggerated.

\section{B. Conceptual model}

NORTHWEST

A

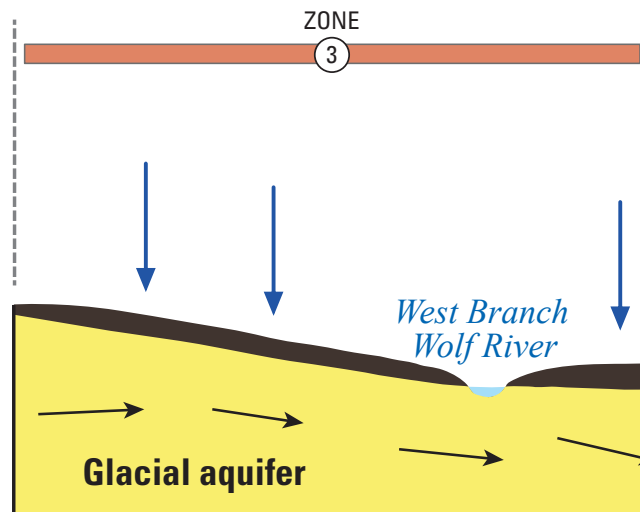

\section{Crystalline bedrock}

Vertical dimension is greatly exaggerated.

\section{EXPLANATION}

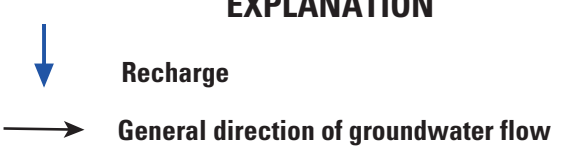

Figure 3. The groundwater-flow system of the Menominee Indian Reservation, Wisconsin. $A$, Idealized cross section. $B$, Conceptual model developed to guide construction of the groundwater-flow model. GFLOW, the groundwater-flow modeling code, requires a horizontal aquifer base (top of crystalline bedrock). Zone numbers in figure $3 B$ correspond with zone numbers in figure 4. 
from zero (in areas near Precambrian bedrock outcrops) to approximately $150 \mathrm{ft}$. The regional groundwater-flow direction generally matches that of the rivers, flowing from the northwest toward the southeast as more complex local flow patterns interact with local rivers and lakes (plate 3 of Krohelski and others, 1994).

\section{Sources and Sinks of Water}

The primary source of water to the groundwater-flow system on the Menominee Indian Reservation is precipitation that infiltrates through the ground to the water table-a process known as recharge and expressed as a rate in inches per year. Groundwater moves from higher to lower hydraulic potential (areas of higher groundwater levels to areas of lower groundwater levels). As a result, water generally enters the groundwater system areally throughout the reservation and discharges to surface-water features. These features behave as groundwater sinks in the model, where groundwater leaves the aquifer to become surface water. Accurate locations of surface-water features are, therefore, critical to simulating the groundwater system and groundwater/surface-water interaction within the reservation.

Pumped wells are another type of hydrological sink, capturing groundwater that would otherwise discharge to rivers, lakes, and wetlands. In areas of significant groundwater withdrawal by wells, rivers that otherwise would receive groundwater as base flow may instead locally recharge the groundwater system (Feinstein and others, 2012). Only a small amount of the total recharge to the water table within the reservation is captured by wells. However, areas with large annual withdrawals (for example, the city of Keshena) can capture a substantial portion of the local recharge.

\section{Hydrogeologic Boundaries}

The groundwater-flow model consists of two domains: the near field and the far field. The near field is the area of interest, which for this study is the entire Menominee Indian Reservation. The near-field rivers and lakes are represented by linesink networks (Haitjema, 1995). A linesink is a mathematical representation of a hydrologic sink (such as a stream), and a network of such linesinks will route base flow (the portion of total flow derived from groundwater) downstream. The degree of groundwater/surface-water interaction at a particular river segment depends on the riverbed sediment resistance (thickness divided by vertical hydraulic conductivity) and the difference in elevation between the river stage and the adjacent water table. The headwaters of certain river systems surrounding the reservation were simulated as near-field linesinks in order to allow the simulated river to "go dry" if the water table is simulated as being below the riverbed elevation, which removes the linesink from the solution. This is an important consideration near groundwater divides where ephemeral streams tend to be prevalent.
The model far field is the area surrounding the near field and contains hydrologic features that control the groundwater flow toward or away from the near field. These features are rivers and lakes that border the reservation and are simulated with coarsely defined linesink networks having little or no resistance between the surface-water features and the groundwater system. The function of the far field is to establish the groundwater divides near the edge of the model that to a large extent determine the flow of water to sinks (rivers, lakes, wetlands, and wells) within the near field. The importance of properly simulated model boundaries is to ensure that simulated responses to stresses applied to the near field (for example, pumping or other scenario simulations) are not artificially affected by conditions at the boundaries of the model domain. An efficient way to design boundaries is to have the groundwater-flow model directly simulate hydraulic divides between the area of interest (near field) and adjacent rivers (Anderson and Woessner, 1992; Haitjema, 1995).

\section{Hydraulic Properties of the Groundwater-Flow System}

Initial estimates of aquifer hydraulic conductivity, recharge, and riverbed resistance for the regional groundwaterflow model were based on available geologic and hydrologic data. The following is a brief description of these estimates. Final values were derived during the parameter-estimation process.

\section{Hydraulic Conductivity}

Glacial lithologies within the Menominee Indian Reservation were mapped by Farrand and others (1984) as glacial tills (loamy and calcareous sandy loamy), outwash sand and gravel, and minor deposits of glacial lakebed silts and clays. Whereas these descriptions suggest a potentially large range in lithology and associated hydraulic conductivities, descriptions from reports and maps by Hooyer and Mode (2007), Mickelson (1986), and Hadley and Pelham (1976) describe relatively modest variation among most tills in the area, with most tills being composed primarily of sand. Moreover, glacial maps rarely consider the degree of connectivity among clay units, a factor that is important for making regional-scale hydraulic-conductivity estimates. Hydraulic conductivity of the surficial glacial aquifer ranged from 0.1 to 55 feet per day (ft/d) for 11 slug tests conducted within the reservation, as reported in Krohelski and others 1994.

Pumping tests conducted on the Zoar community wells in the 1970 s provide a further estimate for hydraulic conductivity of the glacial aquifer in this region of the Menominee Indian Reservation. The pumping rates and measured drawdowns for wells Zoar 1 and Zoar 2 (Menominee Tribe of Wisconsin, Department of Environmental Services, written commun., 
2001) were first used to calculate the specific capacity of the aquifer (table 1). The specific-capacity values are the basis for estimating hydraulic conductivity by means of the program TGUESS (Bradbury and Rothschild, 1985). The value of the aquifer storage coefficient is an input to the TGUESS program; a range of values ( 0.01 to 0.0001$)$ was used to provide a range of estimated hydraulic conductivities. On the basis of these storage coefficients and the pumping-test data, locally calculated hydraulic conductivities range from 17.3 to $19.5 \mathrm{ft} / \mathrm{d}$. The results were very similar among the three tests conducted on the two Zoar wells, and the hydraulic-conductivity estimates fall within the range of the values estimated previously from slug tests (Krohelski and others, 1994).

The hydraulic conductivity of the crystalline bedrock is estimated to be $0.3 \mathrm{ft} / \mathrm{d}$ (Krohelski, and others, 1994). This is between 1 and 2 orders of magnitude less than that of the glacial aquifer. In the model, the crystalline bedrock is simplified to represent an impermeable boundary even though locally it may have some secondary permeability.

Although these ranges and estimates are useful for characterizing the system, the model requires specific values for the hydraulic conductivity across regions, or zones, in the flow system. Thus, on the basis of available data, values associated with zones of locally uniform hydraulic conductivity were treated as calibration parameters. These zones were delineated by considering multiple geologic maps and descriptions of glacial material along with topographic features. Values used in the modeling described here were initialized by using reasonable values, with the final values determined during calibration by use of PEST (Doherty, 2012) and constrained to a reasonable range based on available measurements and estimates.

\section{Recharge}

Recharge takes place nearly everywhere on the reservation except in groundwater discharge areas associated with surface-water bodies. Recharge in the Menominee Indian Reservation and upstream areas ranges from about 5 to 12 inches per year, as determined from base flows in gaged streams divided by the gaged area (Gebert and others, 2011). The magnitude of estimated recharge can vary spatially as a result of the characteristics of the watershed (precipitation, lithology, topography, land cover and use, evapotranspiration, and so forth), and also from stream capture of groundwater from adjacent surface watersheds that are not coincident with groundwater basins. These local differences tend to average out over large areas such as the Menominee Indian Reservation and show little spatial trend within or upstream of the reservation. Thus, an average recharge rate was applied uniformly across the regional model and was treated as a calibration parameter, with the value constrained to reasonable ranges and determined by use of the parameter estimation code PEST to match observed water levels and base flows.

Table 1. Pumping-test data and TGUESS calculations for production wells near Zoar, Menominee Indian Reservation, Wisconsin.

[(gal/min)/ft, gallons per minute per foot; $\mathrm{ft}^{2} / \mathrm{d}$, feet squared per day; $\mathrm{ft} / \mathrm{d}$, feet per day]

\begin{tabular}{lccc}
\hline \multicolumn{1}{c}{ Well parameter } & Zoar well 1 & $\begin{array}{c}\text { Zoar well 2 } \\
\text { [low pump rate] }\end{array}$ & $\begin{array}{c}\text { Zoar well 2 } \\
\text { [high pump rate] }\end{array}$ \\
\hline Well diameter (inches) & 6.0 & 8.0 & 8.0 \\
Total depth (feet) & 86.0 & 82.0 & 82.0 \\
Static water level (feet) & 12.0 & 18.2 & 18.2 \\
Saturated thickness (feet) & 75.5 & 64.8 & 64.8 \\
Open interval (feet) & $74.0-86.0$ & $72.0-82.0$ & $72.0-82.0$ \\
& & & \\
Test date & $12 / 04 / 75$ & $05 / 03 / 77$ & $05 / 03 / 77$ \\
Test duration (hours) & 3 & 2 & 2 \\
Pump rate (gallons per minute) & 60 & 60 & 73.3 \\
Final depth to water (feet) & 47.8 & 55.9 & 65.7 \\
Well loss (assumed) & 0.8 & 0.8 & 0.8 \\
Storage coefficient (range) & $0.01-0.0001$ & $0.01-0.0001$ & $0.01-0.0001$ \\
& & & 1.54 \\
Specific capacity [(gal/min)/ft)] & 1.68 & 1.59 & $1,115-1227$ \\
Transmissivity (ft $\left.{ }^{2} / \mathrm{d}\right)$ & $1,339-1,460$ & $1,149-1,270$ & $17.3-18.9$ \\
Hydraulic conductivity (ft/d)* & $17.7-19.3$ & $17.8-19.5$ &
\end{tabular}




\section{Riverbed Resistance}

Estimates of riverbed and lakebed resistance are needed to simulate the interaction between surface water and groundwater. Bottom resistance for a water body is equal to the thickness of a riverbed or lakebed divided by its vertical hydraulic conductivity. In this model, riverbed resistance was set at 0.5 day. (The unit "day" is a mathematical reduction resulting from thickness, in feet, being divided by the hydraulic conductivity, in feet per day.) Resistance was set at 1 day for lakes that outlet to rivers and 10 days for lakes with no surface inflow/outflow. These values correspond to a 1-ft sediment thickness and vertical hydraulic conductivities of 2,1 , and $0.1 \mathrm{ft} / \mathrm{d}$, respectively, and are within commonly observed ranges for bed sediment (Calver, 2001). Because of the relative insensitivity of the regional flow system to riverbed resistance (see "Sensitivity Analysis" section), this parameter was not adjusted during calibration but was evaluated during the Monte Carlo analysis.

\section{Groundwater Withdrawals}

Groundwater withdrawals from the glacial aquifer were incorporated into the GFLOW model according to the conceptual model design. Pumping rates for high-capacity production wells were computed as the annual average rate provided by Indian Health Service (Kevin Staus, written commun., 2013).
Pumping from small, individual private wells in the reservation is not included in the model because the discharge from these wells is widely distributed and relatively small (especially when including return flow from septic systems), so it has a negligible effect on the overall regional water table.

Total high-capacity well withdrawal in the Menominee Indian Reservation is about 117.6 million gallons per year (Mgal/yr) distributed across 13 different wells on the reservation. The largest municipal withdrawals in the model were in Keshena (60.3 Mgal/yr) and Neopit (32.9 Mgal/yr). These and other production wells are listed in table 2 . The groundwaterflow model included three production wells from outside of the reservation - the Dumke C wells of the Stockbridge Munsee Tribe, which withdrew water at about $27.4 \mathrm{Mgal} / \mathrm{yr}$ total.

\section{Simulation of the Regional Groundwater-Flow System}

An analytic element groundwater-flow model of the Menominee Indian Reservation was developed by using the computer program GFLOW (Haitjema, 1995). The model simulates the groundwater-flow system and its interaction with surface-water features. The model consists of one layer and simulates steady-state conditions (no change in water levels over time). Simulated rivers and lakes, and zones of hydraulic conductivity are shown in figure 4.

Table 2. Groundwater withdrawal rates for production wells simulated in the groundwater-flow model of the Menominee Indian Reservation, Wisconsin.

[gal/yr, gallons per year; gal/d, gallons per day; $\mathrm{ft}^{3} / \mathrm{d}$, cubic feet per day]

\begin{tabular}{|c|c|c|c|c|}
\hline Well Name & $\begin{array}{l}\text { Pumping rate } \\
\text { (gal/yr) }\end{array}$ & $\begin{array}{l}\text { Pumping rate } \\
\text { (gal/d) }\end{array}$ & $\begin{array}{l}\text { Pumping rate } \\
\left(\mathrm{ft}^{3} / \mathrm{d}\right)\end{array}$ & $\begin{array}{c}\text { Total pumping } \\
\text { by community } \\
\text { (gal/yr) }\end{array}$ \\
\hline Keshena 3 & $20,088,750$ & 55,000 & 7,352 & \multirow{3}{*}{$60,266,250$} \\
\hline Keshena 4 & $20,088,750$ & 55,000 & 7,352 & \\
\hline Keshena 5 & $20,088,750$ & 55,000 & 7,352 & \\
\hline Zoar 3 & $2,995,050$ & 8,200 & 1,096 & \multirow{3}{*}{$8,985,150$} \\
\hline Zoar 4 & $2,995,050$ & 8,200 & 1,096 & \\
\hline Zoar 5 & $2,995,050$ & 8,200 & 1,096 & \\
\hline Neopit 3 & $10,957,500$ & 30,000 & 4,010 & \multirow{3}{*}{$32,872,500$} \\
\hline Neopit 4 & $10,957,500$ & 30,000 & 4,010 & \\
\hline Neopit 5 & $10,957,500$ & 30,000 & 4,010 & \\
\hline Middle Village well & $7,852,875$ & 21,500 & 2,874 & $7,852,875$ \\
\hline Redwing well 1 & $2,483,700$ & 6,800 & 909 & \multirow{2}{*}{$4,967,400$} \\
\hline Redwing well 3 & $2,483,700$ & 6,800 & 909 & \\
\hline Onekewat well & $2,629,800$ & 7,200 & 963 & $2,629,800$ \\
\hline Stock-Bridge Dumke C well 1 & $9,131,250$ & 25,000 & 3,342 & \multirow{3}{*}{$27,393,750$} \\
\hline Stock-Bridge Dumke C well 2 & $9,131,250$ & 25,000 & 3,342 & \\
\hline Stock-Bridge Dumke C well 3 & $9,131,250$ & 25,000 & 3,342 & \\
\hline
\end{tabular}




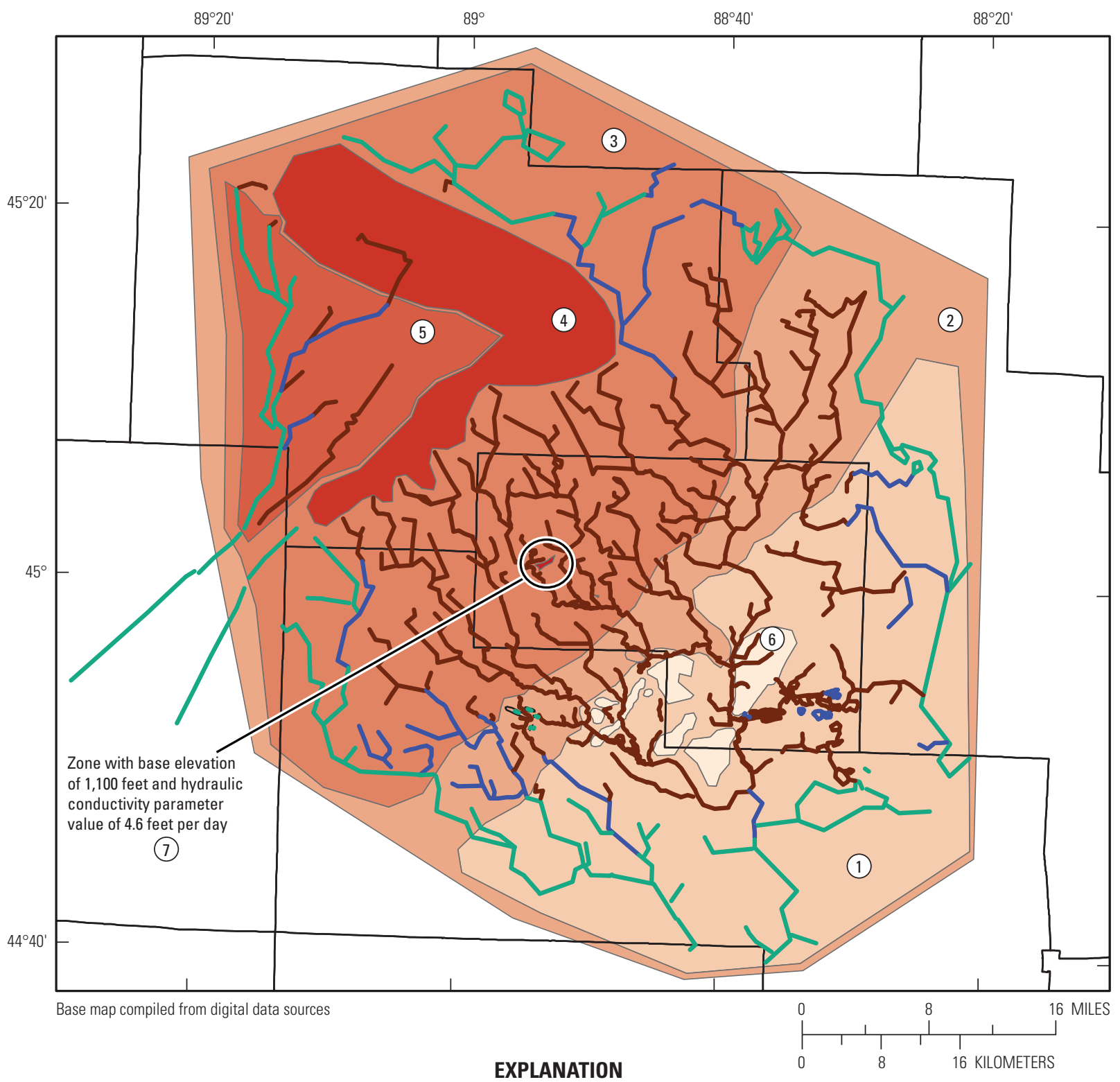

Base elevation (in feet above NAVD 88)

Hydraulic conductivity parameter (in feet per day)

\begin{tabular}{|c|c|c|c|}
\hline X & EXAMPLE & $X X X f t, X . X f t / d, X . X f t / d$ & \\
\hline (6) & & $400 \mathrm{ft}, 0.5 \mathrm{ft} / \mathrm{d}, 4.4 \mathrm{ft} / \mathrm{d}$ & \\
\hline 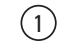 & & $400 \mathrm{ft} ; 8 \mathrm{ft} / \mathrm{d}, 21.3 \mathrm{ft} / \mathrm{d}$ & County boundary \\
\hline (2) & & $500 \mathrm{ft} ; 2.9 \mathrm{ft} / \mathrm{d}, 21.7 \mathrm{ft} / \mathrm{d}$ & linesink \\
\hline & & $600 \mathrm{ft} ; 4.6 \mathrm{ft} / \mathrm{d}, 21.5 \mathrm{ft} / \mathrm{d}$ & $\begin{array}{l}\text { Nonrouted near-field } \\
\text { linesink }\end{array}$ \\
\hline 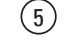 & & $700 \mathrm{ft} ; 18.5 \mathrm{ft} / \mathrm{d}, 64.9 \mathrm{ft} / \mathrm{d}$ & Far-field linesink \\
\hline (4) & & $700 \mathrm{ft} ; 12.3 \mathrm{ft} / \mathrm{d}, 43.1 \mathrm{ft} / \mathrm{d}$ & \\
\hline (7) & & $1,100 \mathrm{ft} ; 4.6 \mathrm{ft} / \mathrm{d}, 16.1 \mathrm{ft} / \mathrm{d}$ & \\
\hline
\end{tabular}

Figure 4. Hydrologic features and base elevation and hydraulic-conductivity zones simulated with analytic elements, Menominee Indian Reservation, Wisconsin. 


\section{Model Construction and Assumptions}

Initial model development included estimating the elevation of the base of the groundwater system, a recharge rate, and a horizontal hydraulic conductivity. The base of the model is set at $400 \mathrm{ft}$ above NAVD 88 for the southeastern part of the reservation (zone 1). The model base increased to $500 \mathrm{ft}$ for the central part (zone 2) and $600 \mathrm{ft}$ for northwestern part of the reservation (zone 3), representing the increasing elevation of the crystalline bedrock. Smaller areas that were expected to have different geologic lithologies were separated into individual zones (zones 4, 5, and 6) but maintained the simulated bedrock elevation from the surrounding area. A local bedrock high near the village of Zoar (zone 7) that was identified through borings was assigned a base elevation of $1,100 \mathrm{ft}$ above NAVD88. The regional base elevations are hundreds of feet below the mapped bedrock elevations in the area (Krohelski and others, 1994) but generally match the regional bedrock dip. Lower-than-actual base elevations were used as a means to improve performance of the model and stability of the conjunctive groundwater and surface-water solution for the model; hydraulic-conductivity adjustments were applied to ensure proper representation of the bulk aquifer transmissivity; that is, the combination of zones with flat bases (a requirement of analytic element methods) and the sloping streams resulted in thin saturated thicknesses in the model when more realistic base elevations were used. This thin saturated thickness amplifies problems associated with nonlinearity of the conjunctive groundwater and surface-water solution. Beyond adjusting solver settings (such as numerical relaxation), increasing the simulated saturated thickness in the model by using low base elevations reduced nonlinearity problems and stabilized the model solution, resulting in an improved simulation.

In two-dimensional areal models, where transmissivity (hydraulic conductivity multiplied by aquifer saturated thickness) of a single layer represents the flow system, the base elevation is correlated with hydraulic conductivity; that is, the same aquifer transmissivity can be represented with a thick aquifer and low hydraulic conductivity values as could be represented by a thin aquifer and high conductivities. Therefore, parameter calibration focused on hydraulic conductivity in each zone rather than the aquifer base elevations. Use of lower-than-actual base elevations, or overestimating saturated thickness, resulted in estimates of hydraulic-conductivity parameter values that were lower than computed hydraulic conductivities from pumping tests. As a result, the calibrated hydraulic-conductivity parameter values listed in table 3 are only reasonable for the base elevations used in this model. More realistic effective hydraulic conductivity estimates for simulated zones in the model are listed in table 4 . These calculated effective hydraulic-conductivity values were computed by adjusting for more realistic saturated thicknesses based on mapped bedrock elevations. The effective hydraulic-conductivity and adjusted saturated-thickness values generally match values computed from pumping-test results near the village of Zoar (table 1).
This representation of transmissivity has two noteworthy implications for model simulations. First, the range in simulated transmissivity within an inhomogeneity is less than would have been simulated by using shallow base elevations. This result is viewed as a positive attribute of the model because the actual bedrock surface is sloped, and not horizontal with discrete step changes in elevation, as must be simulated with analytic elements; that is, the relatively more subtle simulated changes in transmissivity within and across zones is likely more representative of the natural system than would have been simulated with zones of very shallow bedrock surfaces. Second, simulated groundwater traveltimes are affected by saturated thickness (for example, Vogel, 1967; Haitjema, 1995). That is, groundwater velocity is computed according to equation 1, as modified from Anderson and Woessner (1992):

$$
v=-\frac{K}{n_{e}} \frac{d h}{d l}=-\frac{T}{n_{e} b} \frac{d h}{d l}
$$

where

\begin{tabular}{|c|c|}
\hline$v$ & $\begin{array}{l}\text { is the velocity of groundwater flowing } \\
\text { through connected pore spaces, }\end{array}$ \\
\hline K & is the aquifer hydraulic conductivity, \\
\hline$n_{e}$ & $\begin{array}{l}\text { is the aquifer effective porosity (the } \\
\text { porosity available for groundwater } \\
\text { movement), which is referred to simply as } \\
\text { porosity in this report, }\end{array}$ \\
\hline$d h / d l$ & $\begin{array}{l}\text { is the hydraulic gradient, or change in water level } \\
\text { divided by change in distance, }\end{array}$ \\
\hline$b$ & is the saturated thickness of the aquifer, and \\
\hline$T$ & $\begin{array}{l}\text { is the aquifer transmissivity, which is } \\
\text { equal to } K^{*} b \text {. }\end{array}$ \\
\hline
\end{tabular}

Similar to the adjustment of hydraulic conductivity as a means to maintain reasonable aquifer transmissivities in the model due to the exaggerated saturated thickness simulated in the model, porosity was locally adjusted to maintain realistic groundwater velocity and traveltime simulations around pumped wells. For example, doubling the simulated saturated thickness would require halving the aquifer porosity in order to produce an "adjusted" porosity value for use in the model that would maintain appropriately simulated traveltimes. The estimated aquifer porosity $(0.2)$ and corresponding adjusted porosity values used in the model are provided in table 5 .

The river network for the Menominee Indian Reservation (fig. 1) is represented in the GFLOW model as a series of linesinks (fig. 4). Multiple linesinks are joined into linesink strings representing river segments with uniform downstream slope (change in water-surface elevation over distance). The river slope assigned to linesink strings in the Menominee Indian Reservation model was based on data from 7.5-minute topographic quadrangle maps. GFLOW solves for the exchange between groundwater and surface water at the center of each linesink. 
Table 3. Calibrated and specified parameter values and composite sensitivities for the groundwater-flow model of the Menominee Indian Reservation, Wisconsin.

[in/yr, inches per year; ft/d, feet per day]

\begin{tabular}{|c|c|c|c|}
\hline Parameter name & $\begin{array}{l}\text { Calibrated or specified } \\
\text { parameter value }\end{array}$ & $\begin{array}{l}\text { Sensitivity } \\
\text { (no units) }\end{array}$ & $\begin{array}{c}\text { Description } \\
\text { (from Farrand and others, 1984) }\end{array}$ \\
\hline R_reservation & $8.4 \mathrm{in} / \mathrm{yr} ;$ calibrated & 0.08 & Uniform recharge to the entire model area. \\
\hline K_southeast & $8.0 \mathrm{ft} / \mathrm{d}$; calibrated & 0.13 & $\begin{array}{l}\text { Hydraulic-conductivity parameter for the southeastern } \\
\text { part of the model area, representing sandy loamy till } \\
\text { and outwash sand and gravel glacial deposits. }\end{array}$ \\
\hline K_central & $2.9 \mathrm{ft} / \mathrm{d}$; calibrated & 0.07 & $\begin{array}{l}\text { Hydraulic-conductivity parameter for the central part } \\
\text { of the model area, representing sandy, loamy till and } \\
\text { outwash sand and gravel glacial deposits. }\end{array}$ \\
\hline K_northwest & $4.6 \mathrm{ft} / \mathrm{d}$; calibrated & 0.12 & $\begin{array}{l}\text { Hydraulic-conductivity parameter for the northwestern } \\
\text { part of the model area, representing sandy, loamy till } \\
\text { and outwash sand and gravel glacial deposits. }\end{array}$ \\
\hline K_antigo_outwash_mult & 1.5 ; calibrated & 0.006 & $\begin{array}{l}\text { Multiple of the K_sandy_till parameter representing } \\
\text { outwash sand and gravel in the Antigo area of the } \\
\text { model. }\end{array}$ \\
\hline K_sandy_till & $12.3 \mathrm{ft} / \mathrm{d}$; calibrated & 0.07 & $\begin{array}{l}\text { Hydraulic-conductivity parameter for the sandy till } \\
\text { deposit in the northwestern part of the model area } \\
\text { east of Antigo. }\end{array}$ \\
\hline K_loamy_till & $0.5 \mathrm{ft} / \mathrm{d}$; calibrated & 0.07 & $\begin{array}{l}\text { Hydraulic-conductivity parameter for loamy till depos- } \\
\text { its in the southeastern part of the model area. }\end{array}$ \\
\hline C_drainage_lakes & 1.0 day; specified & 0.003 & $\begin{array}{l}\text { Lakebed resistance for drainage lakes (have an outlet } \\
\text { stream) simulated with routed linesinks. }\end{array}$ \\
\hline C_seepage_lakes & 10 days; specified & 0.005 & $\begin{array}{l}\text { Lakebed resistance for seepage lakes (no outlet stream) } \\
\text { simulated with nonrouted linesinks. }\end{array}$ \\
\hline C_rivers & 0.5 day; specified & 0.02 & $\begin{array}{l}\text { Riverbed resistance for perennial rivers simulated with } \\
\text { routed and nonrouted near-field linesinks. }\end{array}$ \\
\hline
\end{tabular}

Table 4. Calibrated hydraulic-conductivity parameters and associated base elevations used to calculate effective hydraulic-conductivity estimates for the Menominee Indian Reservation, Wisconsin.

[ft, feet; ft/d, feet per day; NAVD 88, North American Vertical Datum of 1988]

\begin{tabular}{|c|c|c|c|c|c|c|c|c|}
\hline $\begin{array}{l}\text { Parameter } \\
\text { name }\end{array}$ & $\begin{array}{l}\text { Estimated } \\
\text { actual } \\
\text { base } \\
\text { elevation } \\
\text { (ft above } \\
\text { NAVD 88) }\end{array}$ & $\begin{array}{c}\text { Base } \\
\text { elevation } \\
\text { in } \\
\text { GFLOW } \\
\text { (ft above } \\
\text { NAVD 88) }\end{array}$ & $\begin{array}{l}\text { Estimated } \\
\text { average water } \\
\text { level from the } \\
\text { calibrated } \\
\text { GFLOW model } \\
\text { (ft above } \\
\text { NAVD 88) }\end{array}$ & $\begin{array}{c}\text { Simulated } \\
\text { saturated } \\
\text { thickness } \\
\text { (ft) }\end{array}$ & $\begin{array}{l}\text { Calculated } \\
\text { actual } \\
\text { saturated } \\
\text { thickness } \\
\text { (ft) }\end{array}$ & $\begin{array}{l}\text { Calibrated } \\
\text { hydraulic- } \\
\text { conductivity } \\
\text { parameter } \\
\text { (ft/d) }\end{array}$ & $\begin{array}{l}\text { Calculated } \\
\text { effective } \\
\text { hydraulic } \\
\text { conductivity } \\
\text { (ft/d) }\end{array}$ & $\begin{array}{c}\text { Geologic } \\
\text { description } \\
\text { (from Farrand } \\
\text { and others, } \\
\text { 1984) }\end{array}$ \\
\hline K_central & 950 & 500 & 1,020 & 520 & 70 & 2.9 & 21.7 & $\begin{array}{l}\text { Mix of outwash } \\
\text { and till }\end{array}$ \\
\hline K_northwest & 1,150 & 600 & 1,300 & 700 & 150 & 4.6 & 21.5 & $\begin{array}{l}\text { Mix of outwash } \\
\text { and till }\end{array}$ \\
\hline K_shallow_base & 1,150 & 1,100 & 1,170 & 70 & 20 & 4.6 & 16.1 & $\begin{array}{l}\text { Mix of outwash } \\
\text { and till }\end{array}$ \\
\hline K_sandy_till & 1,250 & 600 & 1,510 & 910 & 260 & 12.3 & 43.1 & Sandy till \\
\hline K_loamy_till & 850 & 400 & 910 & 510 & 60 & 0.5 & 4.4 & Loamy till \\
\hline
\end{tabular}

\footnotetext{
${ }^{1}$ Actual base elevation for each zone was estimated from Krohelski and others (1994).
} 
Table 5. Adjusted porosity estimates used to simulate time-dependent areas contributing recharge for pumped wells, Menominee Indian Reservation, Wisconsin. Associated values for estimated and simulated bedrock elevations and saturated thicknesses are included for reference. Effective porosity of the aquifer was estimated at approximately 0.2 , which was locally adjusted within the model simulations to account for simulated biases in the simulated saturated thickness. (Actual base elevations were estimated from wellconstruction reports as available for individual wells. Base elevation was estimated from Krohelski and others, 1994, for wells that did not extend to bedrock.)

[ft, feet; ft/d, feet per day]

\begin{tabular}{|c|c|c|c|c|c|c|c|c|}
\hline $\begin{array}{l}\text { Simulated } \\
\text { area }\end{array}$ & $\begin{array}{l}\text { Estimated } \\
\text { actual } \\
\text { base } \\
\text { elevation } \\
\text { (ft above } \\
\text { NAVD 88) }\end{array}$ & $\begin{array}{c}\text { Base } \\
\text { elevation } \\
\text { in } \\
\text { GFLOW } \\
\text { (ft above } \\
\text { NAVD 88) }\end{array}$ & $\begin{array}{l}\text { Estimated } \\
\text { average water } \\
\text { level from the } \\
\text { calibrated } \\
\text { GFLOW model } \\
\text { (ft above } \\
\text { NAVD 88) }\end{array}$ & $\begin{array}{c}\text { Simulated } \\
\text { saturated } \\
\text { thickness } \\
\text { (ft) }\end{array}$ & $\begin{array}{l}\text { Calculated } \\
\text { actual } \\
\text { saturated } \\
\text { thickness (ft) }\end{array}$ & $\begin{array}{l}\text { Calibrated } \\
\text { hydraulic- } \\
\text { conductivity } \\
\text { parameter } \\
\text { (ft/d) }\end{array}$ & $\begin{array}{l}\text { Calculated } \\
\text { effective } \\
\text { hydraulic } \\
\text { conductivity } \\
\text { (ft/d) }\end{array}$ & $\begin{array}{c}\text { Adjusted } \\
\text { porosity } \\
\text { used in } \\
\text { GFLOW (no } \\
\text { units) }\end{array}$ \\
\hline Redwing wells & 700 & 400 & 845 & 445 & 145 & 8.0 & 24.6 & 0.065 \\
\hline Onekewat wells & 725 & 400 & 846 & 446 & 121 & 8.0 & 29.5 & 0.054 \\
\hline Keshena wells & 780 & 400 & 850 & 450 & 70 & 8.0 & 51.4 & 0.031 \\
\hline $\begin{array}{l}\text { Keshena upgradient } \\
\text { area }\end{array}$ & 800 & 400 & 905 & 505 & 105 & 8.0 & 38.5 & 0.042 \\
\hline Middle Village & 910 & 400 & 994 & 594 & 84 & 0.5 & 3.6 & 0.028 \\
\hline Neopit wells & 990 & 600 & 1,063 & 463 & 73 & 4.6 & 29.2 & 0.032 \\
\hline $\begin{array}{l}\text { Neopit immediately } \\
\text { upgradient area }\end{array}$ & 1,043 & 600 & 1,095 & 495 & 52 & 4.6 & 43.8 & 0.021 \\
\hline $\begin{array}{l}\text { Neopit distant } \\
\text { upgradient area }\end{array}$ & 1,100 & 600 & 1,145 & 545 & 45 & 4.6 & 55.8 & 0.017 \\
\hline Zoar wells & 1,125 & 600 & 1,182 & 582 & 57 & 4.6 & 47.1 & 0.020 \\
\hline Zoar upgradient area & 1,175 & 600 & 1,240 & 640 & 65 & 4.6 & 45.4 & 0.020 \\
\hline
\end{tabular}

In the near field of the model — that is, within and immediately adjacent to the reservation - each linesink is assigned a width based on stream order and field observations; widths ranged from about $5 \mathrm{ft}$ for headwaters to $300 \mathrm{ft}$ along the Wolf River near Keshena. Each near-field linesink is also assigned a resistance term that is equal to the thickness of the riverbed divided by its hydraulic conductivity. This resistance term is multiplied by the river width and the difference between the fixed river level and calculated water-table elevation adjacent to the river to compute groundwater flow across the riverbed. In the regional model, a single value of resistance equal to 0.5 day was applied to all rivers. Initial parameter sensitivities demonstrated that the model results were not sensitive to changes in riverbed resistance when varied over reasonable ranges; therefore, the values for all rivers were fixed for all model runs.

Near-field linesinks are linked so that base flow is routed from headwaters at higher elevations through tributaries to the main trunk of rivers at lower elevations. By routing base flow through the river network, the amount of water gained from or lost to the aquifer system by the river is tabulated. This accounting allows the amount of water simulated in the river at any point to be compared to flows recorded at streamgages. In general, streamflow consists of (1) overland flow derived mostly from storms and (2) base flow derived from groundwater discharge. Only the base-flow component of streamflow is simulated with the GFLOW model.

Drainage lakes, or lakes that have a surface-water outlet, were simulated as linesinks with resistance along their shorelines and assigned widths based on the approximate distance from shoreline to shoreline (Haitjema, 2005) and a uniform resistance of 1 day. Seepage lakes, or lakes that have no surface inlet or outlet, in areas of interest near production wells (Round, Sand, and Long Lakes near the Villages of Onekewat and Redwing) also were simulated with linesinks along their shorelines. These seepage lakes were similarly assigned widths based on the approximate distance from shore to shore and assigned a uniform resistance of 10 days. Simulating seepage lakes with linesinks allowed for uncertainty associated with their relative degree of connection with the water table to be evaluated during Monte Carlo uncertainty simulations. Seepage lakes outside of local areas of interest that were expected to be well connected with the groundwater system were represented in the model as water-level targets. 
Linesinks also represent water bodies in the model "far field" area outside of the reservation (fig. 4). However, these far-field elements are assigned no resistance or width. The assigned stage for each far-field linesink is equivalent to the water-table elevation along the linesink. The far-field linesinks, therefore, act as fixed water-level conditions that serve as important groundwater sinks or sources outside the near field. In this manner, the far-field water bodies help to define the groundwater divides around the outer perimeter of the model. This design ensures that simulated responses to stresses applied to the near field are not artificially affected by conditions at the boundaries of the model domain.

Other inputs to the GFLOW model include pumping wells and recharge zones. Wells are assumed to be fully penetrating (screened from the water table to the model base) and to have constant pumping rates, as described previously (see the "Groundwater Withdrawals" section). Recharge was simulated uniformly across the model. Although some local variation in recharge is expected, such variation "averages out" at the regional scale of the model (see "Recharge" section above). Additional recharge was added to an area in the model representing the seepage cells of the wastewater-treatment facility near the community of Neopit. The steady-state rate of wastewater added to the facility is 86,500 gallons per day (gal/d), as reported by Indian Health Service (Kevin Staus, written commun., 2013), and the model adds this as recharge to the water table.

\section{Model Calibration}

Ground-water model calibration is a process whereby simulated values of groundwater levels and stream base flows are compared to measured values. The GFLOW model was calibrated with the aid of the parameter estimation program PEST (Doherty, 2012). The PEST program automatically adjusts parameter values within a specified reasonable range and compares simulated groundwater levels and stream base flows to measured water levels and base flows after each run of the GFLOW model. With traditional trial-and-error methods, model calibration is considered complete when simulated and observed water levels and flows match "reasonably" well and values for parameters (in this model, hydraulic conductivity and recharge) are considered "reasonable." By contrast, the primary benefit of a properly constructed parameter-estimation routine is the capacity to automatically calculate parameter values that are a quantified best fit between simulated and observed data while also ensuring that parameter values are reasonable.

Although a steady-state model was used (in which groundwater levels do not change with time), measured water levels used for calibration spanned many years, and the location of the data points can be somewhat uncertain. Groundwater-level targets (water levels in wells) were binned into four categories (table 6A) and assigned weights for the calibration process based on their locational accuracy and the amount and type of historical measurements. Assessing the quality and priority of calibration targets and assignment of corresponding weights is important because targets with higher weights are honored by the calibration process more closely than targets with low weights. Although the relative difference among target weights determines their respective influence on the calibration, it is useful to compute weights on the basis of measureable or inferred estimates of accuracy or uncertainty. Five wells with long-term continuous or periodic water-level measurements recorded in the USGS National Water Inventory System (NWIS) database (Dempster, 1990) were assigned the highest weight (1.2), reflecting a relatively low uncertainty (in terms of location, elevation, well construction, and waterlevel measurement precision) associated with these wells. This weight roughly equates with the 95-percent confidence level that the true steady-state water level at each well is within $1.6 \mathrm{ft}$ of the target value (Hill, 1998). Water levels measured in monitoring wells in the area that were installed for site-specific investigations were assigned the second highest weight (0.39) for water-level targets. These targets incorporated accurate locational and well-construction information, but the duration and frequency of water level monitoring varied. Thus, the true water levels for historical monitoring wells were expected to be within $5 \mathrm{ft}$ of the target value at the 95-percent confidence level. Water levels for seepage lakes expected to be well connected with the aquifer also were used as targets, with the target water level derived from topographic maps. These seepage lake water levels are subject to uncertainty associated with seasonal and long-term lake fluctuations and the degree of connection with the underlying aquifer. Thus, water levels for seepage lake targets were expected to be within about $11 \mathrm{ft}$ of the true value. Lastly, well-construction information was obtained from Well Construction Reports (WCRs; Wisconsin Department of Natural Resources, 2010), which contain limited information on the location and elevation of the well site. On the basis of WCR information, the well locations were estimated to the nearest quarter-quarter section for wells that lacked latitude and longitude coordinates. For instances where multiple WCRs were reported for the same location, target water levels were computed as the average water level for all wells. Weights assigned to WCR targets varied (0.05 to 0.18 ) depending upon reported and assumed locational and elevation data. Thus, water levels for WCR targets were expected to be accurate to within about 11 to $39 \mathrm{ft}$. The weighted residuals between the target and simulated values were used by PEST to determine the calibrated best fit.

In addition to water-level targets, base-flow estimates were computed for 40 streamflow sites; the gain in flow between nine sets of streamflow sites also were computed and used as targets for the model calibration (table 6B). Gebert and others (2011) estimated base flow at 123 long-term gaging stations and 1,495 partial-record stations in Wisconsin, of which 4 gaging stations and 23 partial-record stations were available for calibrating the Menominee Indian Reservation groundwater-flow model. Gebert and others (2011) estimated base flow at gaging stations by means of the Base-Flow Index method 
Table 6A. Calibration-target descriptions and results for groundwater and lake-level targets, and associated weights used for calibration with the parameter estimation program PEST. The equivalent standard-deviation-calculated 95-percent confidence interval represents the expected accuracy of an individual target value, in the form of "plus or minus (the specified number of) feet."

[std, standard deviation; CI, confidence interval]

\begin{tabular}{|c|c|c|c|c|c|c|}
\hline Target type & $\begin{array}{c}\text { Number of } \\
\text { targets }\end{array}$ & $\begin{array}{l}\text { Mean } \\
\text { error } \\
\text { (feet) }\end{array}$ & $\begin{array}{l}\text { Mean } \\
\text { absolute } \\
\text { error } \\
\text { (feet) }\end{array}$ & $\begin{array}{c}\text { Root } \\
\text { mean } \\
\text { square } \\
\text { error } \\
\text { (feet) }\end{array}$ & $\begin{array}{l}\text { Weight } \\
\text { (1/std) }\end{array}$ & $\begin{array}{c}\text { Equivalent } \\
\text { standard-deviation- } \\
\text { calculated } \\
95 \% \mathrm{Cl} \\
\text { (feet) }\end{array}$ \\
\hline $\begin{array}{l}\text { Measured water levels } \\
\text { for long-term wells in } \\
\text { the USGS groundwater } \\
\text { observation network }\end{array}$ & 5 & 3.3 & 6.0 & 6.4 & 1.2 & 1.6 \\
\hline $\begin{array}{l}\text { Historical measured water } \\
\text { levels in monitoring } \\
\text { wells in the model area }\end{array}$ & 82 & 7.7 & 10 & 13.8 & 0.39 & 5 \\
\hline $\begin{array}{l}\text { Well Construction Report } \\
\text { (WCR) data with latitude } \\
\text { and longitude data }\end{array}$ & 650 & -3.4 & 11.8 & 15.6 & 0.005 to 0.18 & 11 to 39 \\
\hline $\begin{array}{l}\text { Seepage lake water level } \\
\text { reported on topographic } \\
\text { maps }\end{array}$ & 34 & -0.6 & 9.9 & 13.5 & 0.18 & 11 \\
\hline
\end{tabular}

Table 6B. Calibration-target descriptions and results for stream base flow and base-flow gain targets, and associated weights used for calibration with the parameter estimation program PEST. The equivalent standard-deviation-calculated 90-percent confidence interval represents the expected accuracy of an individual target value, in the form of "plus or minus (the specified number) percent."

$\left[\mathrm{ft}^{3} / \mathrm{s}\right.$, cubic feet per second]

\begin{tabular}{|c|c|c|c|c|c|}
\hline Stream target type & $\begin{array}{c}\text { Range in target } \\
\text { base } \\
\text { flow }\left(\mathrm{ft}^{3} / \mathrm{s}\right)\end{array}$ & $\begin{array}{l}\text { Number of } \\
\text { targets }\end{array}$ & $\begin{array}{c}\text { Mean error } \\
\left(\mathrm{ft}^{3} / \mathrm{s}\right)\end{array}$ & $\begin{array}{l}\text { Mean } \\
\text { percent } \\
\text { error }\end{array}$ & $\begin{array}{l}\text { Equivalent coefficient of } \\
\text { variation-calculated } \\
90 \% \text { confidence interval } \\
\text { (used to compute target weight) }\end{array}$ \\
\hline Historical gaging station & 10 to 620 & 4 & 16.0 & $8 \%$ & $5 \%$ \\
\hline Partial-record gaging station & 1.9 to 121 & 23 & 4.6 & $-64 \%$ & $10 \%$ \\
\hline Miscellaneous measurement site & 1.3 to 145 & 13 & 1.5 & $6 \%$ & $20 \%$ \\
\hline $\begin{array}{l}\text { Gain in flow between select } \\
\text { streamflow targets }\end{array}$ & 0.6 to 59.2 & 9 & 0.8 & $-220 \%$ & $\begin{array}{l}\text { Average of target types used to } \\
\text { compute the gain in flow }\end{array}$ \\
\hline
\end{tabular}


(Wahl and Wahl, 1995; Institute of Hydrology, 1980a; 1980b) for daily streamflows from water year 1970 to water year 1999. A relation-line approach, specific to each partial record station and paired gaging station, was used by Gebert and others (2011) to estimate base flow at partial-record stations. The estimated base flow values computed by Gebert and others (2011) for both gaging stations and partial-record stations were used directly as targets for the groundwater-flow model calibration. In addition, 13 miscellaneous streamflow measurements within the reservation were used to estimate base flow with the statewide regression equation developed by Gebert and others (2011). Weights assigned to base flow targets in PEST (table 6b) were based on the type of base-flow target (gage, partial-record, or miscellaneous measurement site) and the amount of flow so that the influence of both small and large streams on the parameter-estimation process was roughly similar to the influence of water-level targets; that is, the accuracy of each group of base-flow targets and their representation of long-term average conditions was estimated by using a 90-percent confidence level (Hill, 1998) such that target values were as follows: (1) gaging stations were expected to be within 5 percent of the "true" long-term base flow, (2) partial-record stations were expected to be within 10 percent of the "true" long-term base flow, and (3) miscellaneous measurement sites were expected to be within 20 percent of the "true" long-term base flow. The weight assigned to individual base-flow targets were then determined according to the target flow value so that targets of the same type had approximately equal influence on the calibration process.

Only a subset of all possible parameters was estimated by PEST. Parameters were excluded or modified if they were insufficiently sensitive for automated calibration (for example, riverbed resistance) or highly correlated with another parameter (for example, outwash deposits in the Antigo area). In these cases, the parameter was fixed at a reasonable value (riverbed resistance) or tied to another parameter (K_antigo_outwash_mult in table 3 was tied to K_sandy_till). Hydraulic-conductivity parameter values used in the calibrated model are listed in table 3 and shown on figure 4; effective hydraulic conductivities are listed in table 4 and also included on figure 4 after adjusting for the simulated saturated thickness, as described under the heading "Model Construction and Assumptions." As described earlier, calibrated hydraulicconductivity parameter values used in the model are biased low compared with effective hydraulic-conductivity estimates (table 4), owing to the exaggerated saturated thickness used to improve model performance. Thus, the following discussion of aquifer properties focuses on the more transferable effective hydraulic-conductivity estimates that better align with actual saturated thicknesses. The average effective hydraulic conductivity for the majority of the modeled area representing mixed glacial outwash and till extending from the northwest to the southeast parts of the reservation (zones $1,2,3$, and 7) was estimated to be about 16 to $22 \mathrm{ft} / \mathrm{d}$ (table 4, fig. 4). Higher average effective hydraulic conductivities (43 to $65 \mathrm{ft} / \mathrm{d}$ ) were estimated for areas of sandy till (zone 4) and a sand and gravel outwash plain in the northwestern part of the model (zone 5). This area of relatively higher hydraulic conductivity corresponds with mapped geologic units (Farrand and others, 1984) and areas with a relatively lower density of perennial streams. Low stream density is associated with high transmissivity, in that recharge to the water table is effectively transmitted through the aquifer, thereby limiting groundwater mounding and discharge to the land surface, which in turn limits land-surface flooding and the generation of surface streams. Glacial deposits of loamy till were simulated with effective hydraulic conductivities of about $4 \mathrm{ft} / \mathrm{d}$ (zone 6). Recharge to the Menominee Indian Reservation was estimated at $8.4 \mathrm{in} / \mathrm{yr}$ (table 3).

Following calibration, model-simulated groundwater level and streamflow show a close fit to target values (figs. 5 and 6). Unweighted statistics relating all target water levels to all simulated levels include a mean difference of $-2.0 \mathrm{ft}$ (negative indicates that target values are, on average, less than simulated values), a mean absolute difference of $11.5 \mathrm{ft}$, and a root mean squared difference of $15.3 \mathrm{ft}$. Highly weighted targets generally had smaller residuals than targets given lower weight (table $6 A$ ). Simulated water levels generally matched measured (target) water levels over the entire 745 - $\mathrm{ft}$ range of measured water levels (fig. 5) with little spatial bias (fig. 7). All simulated base flows at the gaging stations were within 21 percent of estimated base flows, with a mean percent error of 8 percent. The mean percent error for partial-record stations ( -64 percent) and miscellaneous sites (6 percent) further demonstrate a close fit to target base-flow values (table $6 B$ and fig. 6). The mean percent error for gains in base flow between upstream and downstream target sites ( -220 percent; table $6 B$ ) is dominated by a few targets with very low gains in base flow between sites. However, simulated base flow at the upstream and downstream targets were generally in close agreement with target values (fig. 6). This result illustrates the limited ability of the regional-scale GFLOW model to simulate smallscale gains in base flow without modifying properties, such as riverbed resistance, for site-specific elements or the local hydraulic conductivity. Given that the objectives of this modeling effort were regional in scale, site-specific parameterization was not pursued. Regardless, perfect agreement between measured and simulated values from groundwater-flow models is not expected, because of uncertainties associated with some target data (location, elevation, seasonal variability, well construction, and so on) and simplifications inherent in constructing models of complex natural systems. 


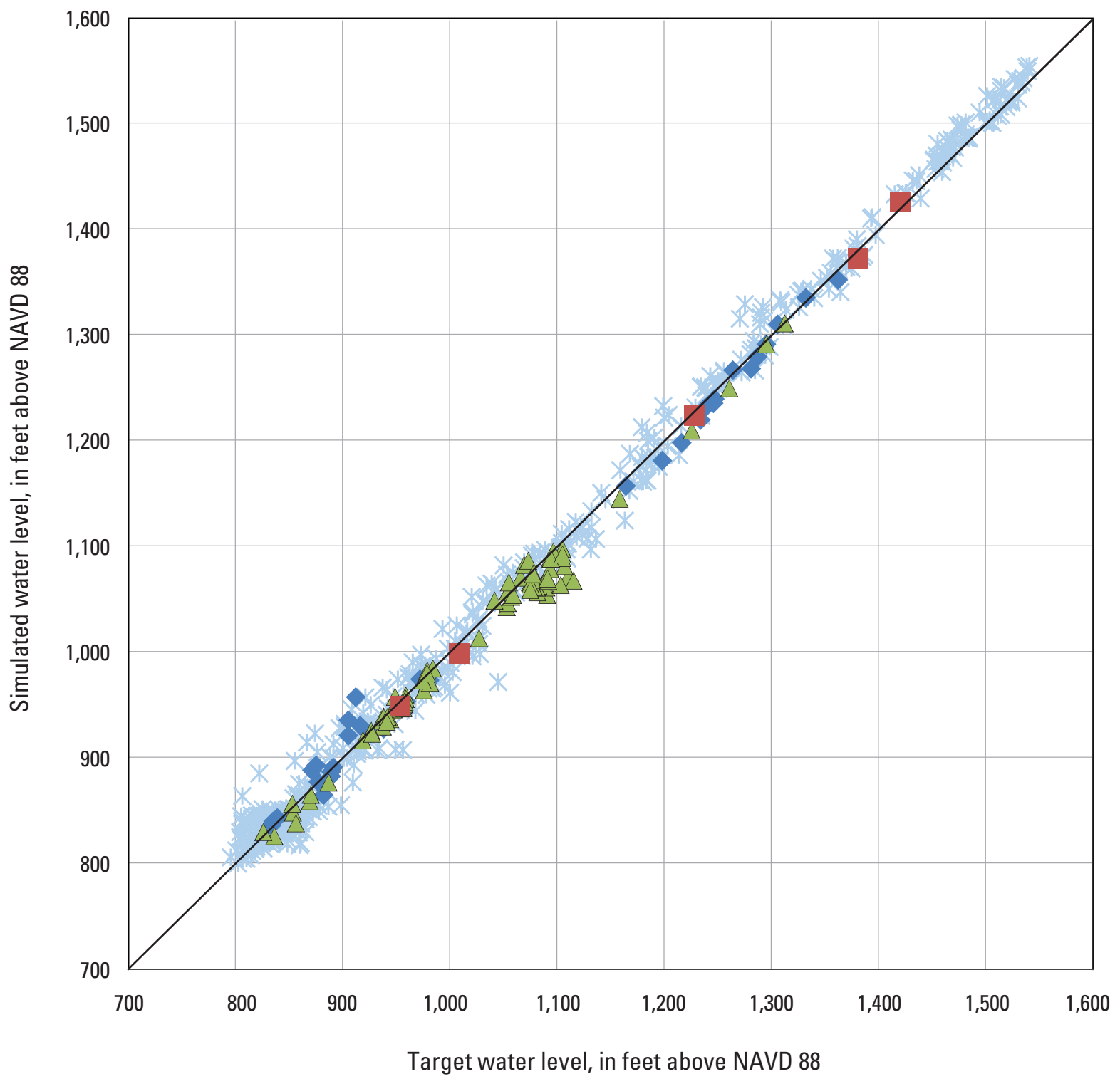

\section{EXPLANATION}

* Water levels from drillers' reports (WCRs)

- Lake water levels from topographic map

$\triangle$ Historical monitoring-well data

USGS Observation Network wells

Figure 5. Simulated water levels in relation to target water levels, Menominee Indian Reservation, Wisconsin. 


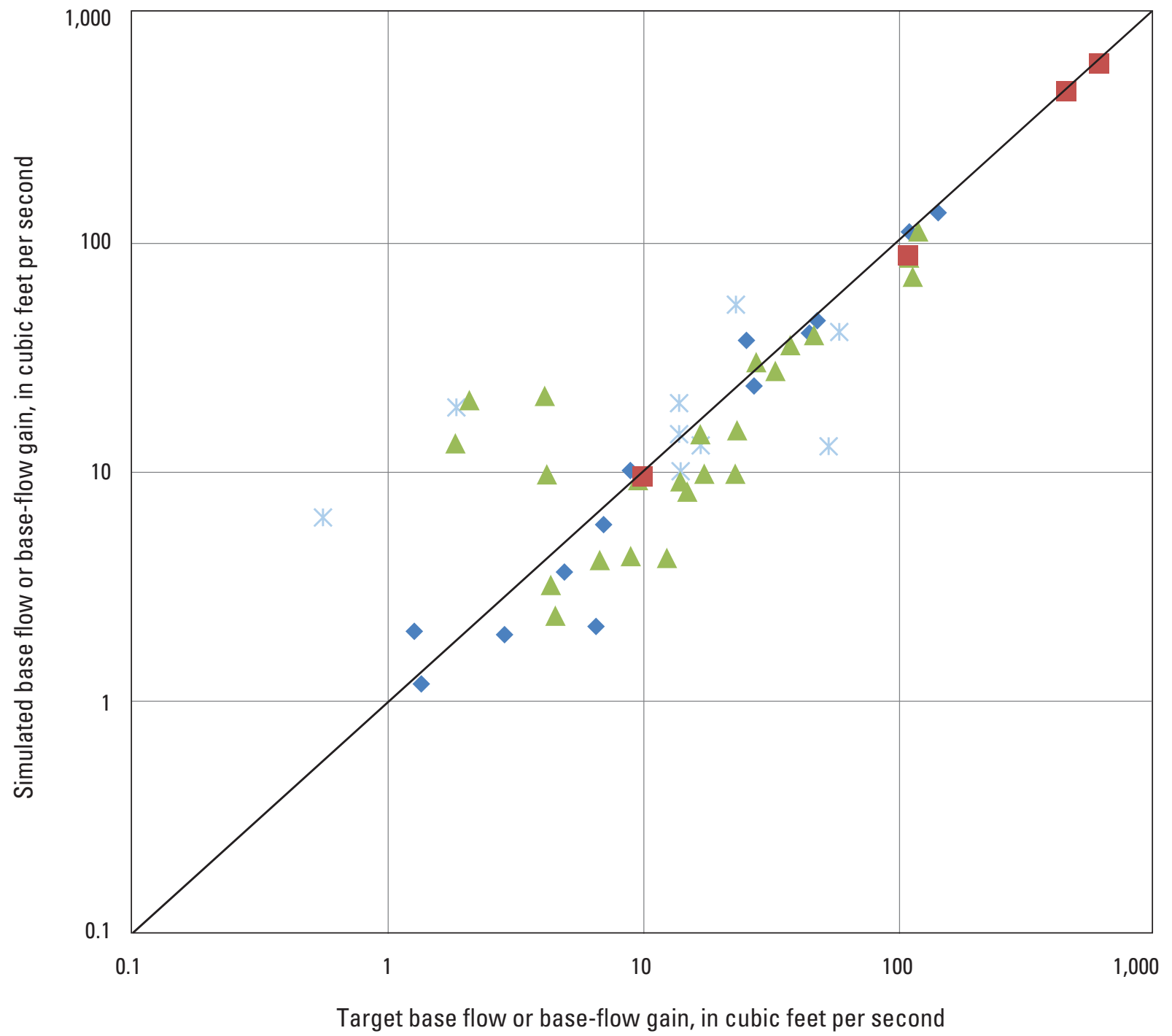

\section{EXPLANATION}

* Gain in flow between base-flow targets

- Miscellaneous measurement sites

$\triangle$ Partial-record stations

- Long-term gaging stations

Figure 6. Simulated base flow and gains in base flow in relation to target base flow and gains in base flow, Menominee Indian Reservation, Wisconsin. 


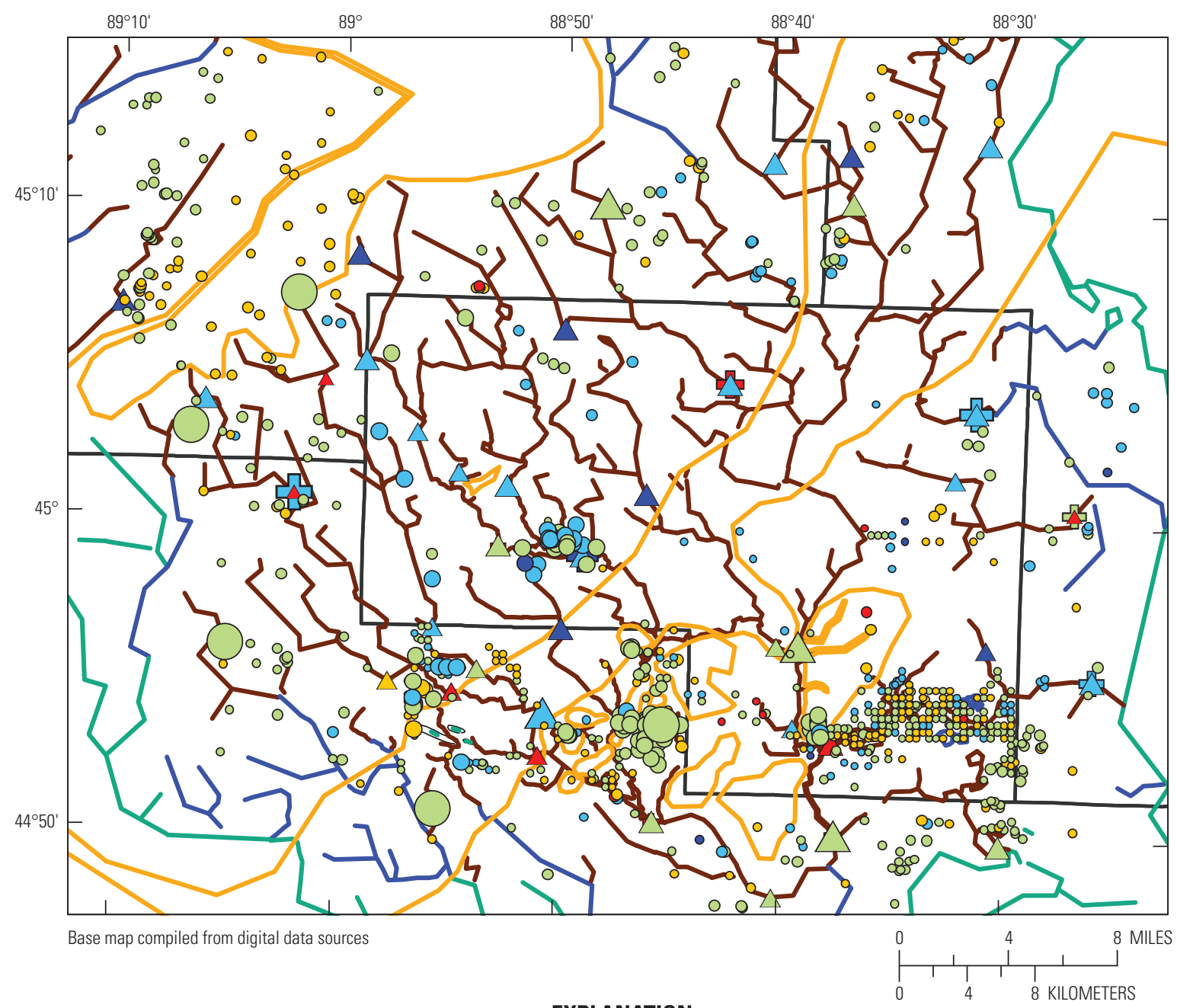

EXPLANATION

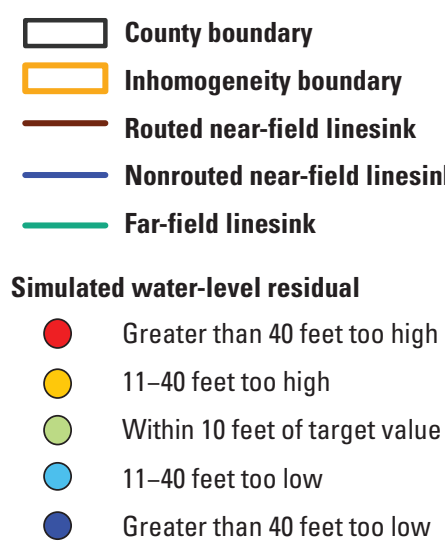

Water-level target type
Simulated base-flow residual (triangle) and base-flow gain residual (cross)
$\triangle$ Greater than 40 percent too high
$\triangle$ گ 10-40 percent too high
$\triangle$ ظ Within 10 percent of target value
$\triangle$ گ 10-40 percent too low
$\Delta$ Greater than 40 percent too low

\section{Base flow target type}

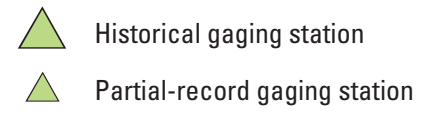

$\triangle \quad$ Miscellaneous measurement site

Figure 7. Water-level- and base-flow-target residuals for the groundwater-flow model of the Menominee Indian Reservation, Wisconsin. The size of base-flow gain targets depends on the base flow target types from which the gains were computed. 


\section{Sensitivity and Uncertainty Analysis}

Some uncertainty about the accuracy of models is inevitable because the model parameter values are never exactly known. However, the importance of each input parameter and its effect on simulation results can be evaluated through sensitivity tests in which the value of a parameter, such as hydraulic conductivity, is adjusted above or below the calibrated value and the magnitude of changes in simulated groundwater levels and base flows are quantified. In this study, PEST was used to calculate the sensitivity of all water-level and base-flow targets to changes in each parameter value during the calibration process. For the final calibrated parameter values, sensitivities computed by PEST (table 3 ) indicate that water levels and streamflows were generally most sensitive to the hydraulicconductivity parameters representing the glacial outwash and till zones covering the majority of the modeled area. Moderately sensitive parameters generally included recharge applied to the model and the hydraulic conductivity of the smaller zones representing local till deposits. Relatively insensitive parameters included sediment resistance for rivers and lakes. Initial sensitivity analyses showed similar results and were used to guide the selection of parameters for estimation.

Although sensitivities are useful for identifying parameters that are important for matching calibration targets, it is not always the case that predictions, such as the area that contributes recharge to wells, will be sensitive to these same calibration parameters; that is, the area contributing recharge may also be sensitive to parameters, such as the sediment resistance for rivers and lakes, which were identified as being of low sensitivity to water-level and base-flow targets during the calibration process. To address this potential confounding factor, a Monte Carlo technique (Starn and Bagtzoglou, 2012) was employed for scenario testing in this report whereby input parameter values were systematically adjusted to generate a range of simulated outcomes. Parameter covariance matrices computed by PEST during the calibration process were used to guide the range around the calibrated values that were tested for all calibrated parameters. For parameters with low sensitivity that were not calibrated, such as lakebed and riverbed resistance, a large variance was specified so that the range of tested values extended more than an order of magnitude from the specified value used in the calibrated model; that is, the range of simulated parameter values was higher for insensitive parameters than for more sensitive parameters, because the calibration data provided more information to constrain the highly sensitive parameters (hydraulic conductivity and recharge). The range of model parameter values were sampled using a Latin Hypercube approach (Starn and Bagtzoglou, 2012) to construct about 800 parameter realizations (combinations of parameter values) for each Monte Carlo simulation. For example, to estimate the area contributing recharge to a pumped well, each parameter in table 3 was assigned about 800 different values that typically ranged higher and lower than the calibrated value by one to two times the calibrated value. For each realization, the GFLOW model was solved and particle traces were evaluated to identify the area contributing recharge to selected wells for that particular realization. (A description of particle tracking is included later under the heading "Simulation of Areas Contributing Recharge to Existing Wells.") Finally, a map of the probability that a well would capture water recharged in adjacent areas was produced by evaluating the area contributing recharge for every realization and was summarized in terms of the percentage of model solutions for which an individual particle of water that started at the water table flowed through the aquifer and was captured by the well. This type of visual representation of probability accounts for uncertainty in the parameter values as they relate to the particular scenario of interest, the model design, and the information content contained by the calibration targets; that is, the Monte Carlo uncertainty analysis is predicated upon the regional model design and calibration and is amenable to local refinements that could modify and improve future uncertainty analyses for local areas. A similar uncertainty analysis using Monte Carlo techniques was performed to estimate the probability of wastewater presence in the aquifer downgradient of wastewater-treatment lagoons near the village of Neopit. Application and results of the Monte Carlo simulations are further described in the subsequent sections "Simulation of Areas Contributing Recharge to Existing Wells" and "Simulation of Flow of Wastewater from Infiltration Lagoons."

\section{Evaluation of Simulated Results of the Menominee Indian Reservation Model}

Results from the regional GFLOW model illustrate simulated water levels and groundwater-flow directions. Figure 8 shows contours of the simulated water table and the path of several simulated particles of water flowing downgradient, starting at the water table and flowing to discharge locations such as wells and streams. The regional groundwater-flow pattern is generally parallel to the direction of flow in most rivers in the reservation; that is, groundwater west of the Wolf River generally flows from the northwest toward the southeast, as do most of the tributary rivers. A groundwater divide forms between the Wolf and Oconto Rivers (fig. 1) in the eastern part of the reservation. East of the Wolf River, groundwater flows both west toward the Wolf River and east toward the Oconto River. Imprinted on top of the regional flow system are local flow patterns that are affected by local aquifer properties and river geometries. As evident by the simulated particle traces in figure 8 , much of the water that enters the aquifer as recharge at the water table within the reservation discharges to nearby rivers.

The GFLOW model for the Menominee Indian Reservation integrates information over a large area and was designed to address regional-scale issues. In addition, the model forms a basis for local refinement or extraction to a three-dimensional model, as necessary. For example, zones of differing hydraulic conductivity are in the model to represent mapped 


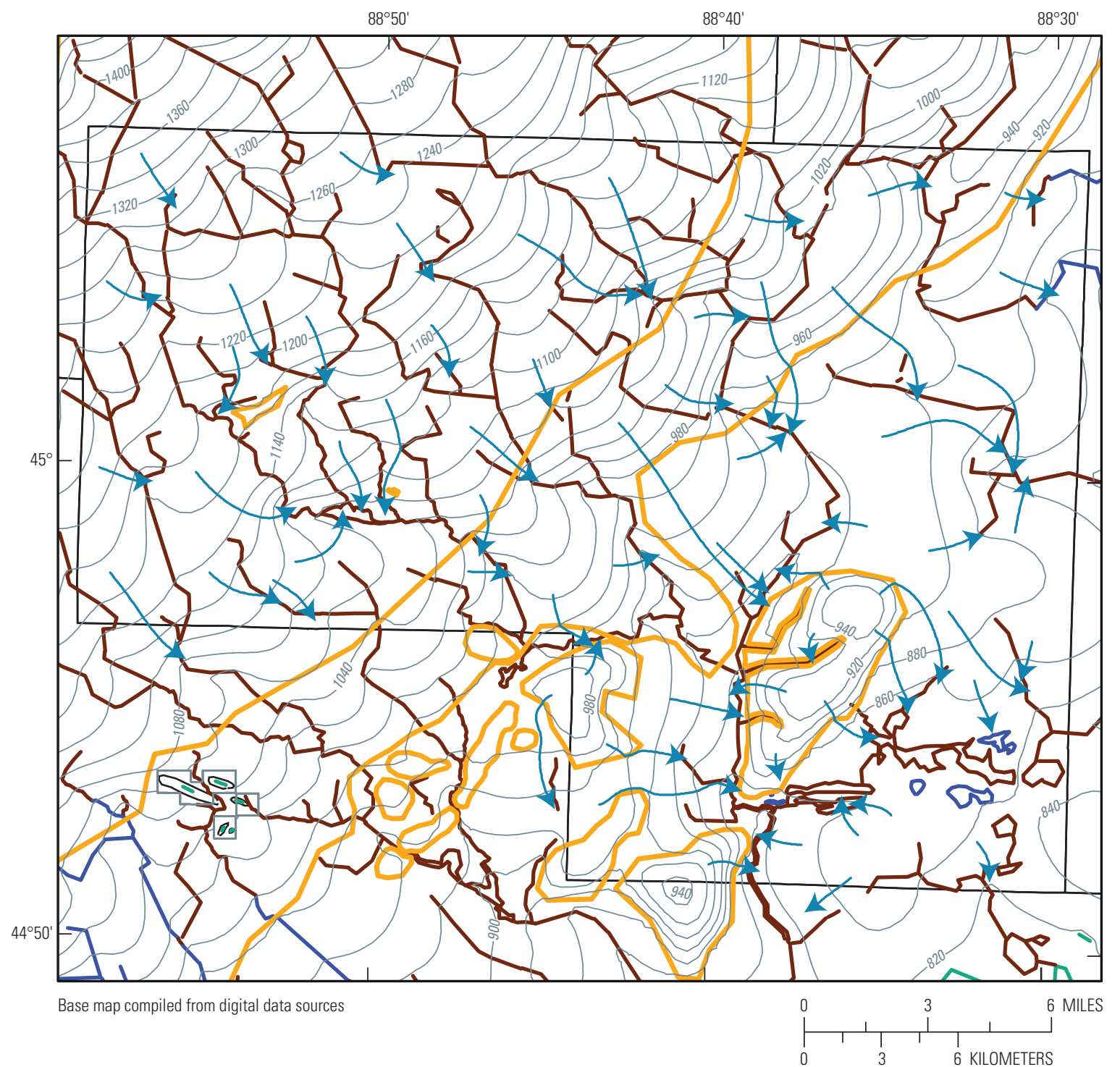

EXPLANATION

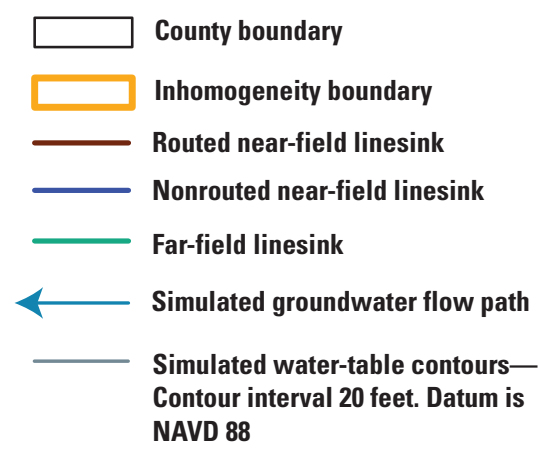

Figure 8. Simulated groundwater-flow directions and water-table contours, Menominee Indian Reservation, Wisconsin. 
geologic changes, such as relatively lower permeability loamy till deposits in the southeastern part of the reservation. This heterogeneity, together with refined linesinks near groundwater withdrawal wells, facilitates application of the model to evaluate the sources of water to existing wells. Possible future studies of specific parts of the reservation or evaluation of sources of water to possible new wells would benefit from an evaluation of the appropriate level of local detail in the model.

\section{Simulation of Areas Contributing Recharge to Existing Wells}

Areas contributing recharge to pumped wells on the reservation were delineated by using forward and backward particle tracking (Haitjema, 1995). Particle tracking is performed by using the simulated water levels and groundwater-flow patterns within the aquifer that are produced as part of the GFLOW model solution to compute the path (and rate) that a mathematical particle of water follows through the aquifer. Because this is a mathematical method, water can be tracked either forward (with the direction of groundwater flow) or backward (opposite the direction of groundwater flow) from multiple specified locations. Both forward and backward tracking were applied for this study.

Forward tracking was used as part of the Monte Carlo uncertainty analysis by first generating a grid of mathematical particles at the water table upgradient of the wells of interest. Next, approximately 800 different combinations of parameter values spanning a reasonable range around the calibrated values (table 3) were generated, with the groundwater-flow model re-solved for each realization. For every realization, all particles were forward-tracked and evaluated as to whether each mathematical particle ultimately was or was not captured by a pumped well, regardless of the simulated traveltime for each particle. Upon completion of all realizations, the percentage of realizations for which each particle was captured by a well was computed. The starting location for each particle was then plotted on a map, with the color code indicating the percentage of realizations, or probability, that the particle would be captured by a nearby well (figs. 9-13). Only particles that had a probability of 1 percent or greater are shown in figures 9-13; additional particles beyond the colored areas were simulated but are not shown because the particles were never captured by a well during any of the approximately 800 Monte Carlo simulations.

Backward particle tracking was used to estimate the agebased areas contributing recharge to each pumped well (for example, the 5-year or 10-year area contributing recharge) for only the calibrated set of parameters. Age-based groundwater traveltimes surrounding pumped wells are often used as a management tool for regulating approved land uses upgradient of wells, where contamination of the aquifer could prove particularly problematic for the desired use of pumped water. Backward particle tracking involved starting approximately
20 mathematical particles along the circumference of the pumped well, with each particle starting at the base of the aquifer in order to ensure the mapped age-based contributing areas were not truncated. The rate at which particles travel through the aquifer was computed by GFLOW as a function of the local groundwater-flow patterns, saturated thickness, recharge rate, and porosity of the aquifer. A uniform porosity of 20 percent was assumed for the entire glacial aquifer. Although this value is on the lower end of the typical range of total porosity for sand-dominated aquifers (Freeze and Cherry, 1979), it is a reasonable estimate of effective porosity for sand-dominated aquifers. Effective porosity is the proportion of the aquifer through which fluids can flow and is often lower than the total porosity, which is simply the ratio of void space to total aquifer volume, including the solid particles. As described earlier, the saturated thickness of the aquifer was exaggerated to improve performance of the GFLOW solution. Therefore, local zones with adjusted porosity values were added to the model in the expected upgradient areas contributing recharge to pumped wells. Adjusted porosity values used in the model were computed by multiplying 20 percent porosity by the ratio of the expected actual saturated thickness (based on local borings and geologic maps) and the simulated saturated thickness. This simple adjustment ensured that simulated groundwater-flow rates approximated rates that would have been simulated had more representative bedrock elevations been used for the GFLOW model. The adjusted porosity values and associated aquifer values are listed in table 5. Areas contributing recharge were delineated at 5-, 10- and 20-year intervals.

The results of simulations show a range in the pattern of simulated areas contributing recharge for individual wells given the parameters evaluated through the Monte Carlo analysis. For example, the area contributing recharge to some wells, such as the village of Keshena wells (fig. 12), display a relatively sharp spatial contrast from areas of high probability of capture to low probability of capture. This sharp gradation in probability is likely a result of the simulated steady-state conditions and the relatively steep hydraulic gradient along the area contributing recharge. This steep hydraulic gradient is the result of the aquifer properties (relatively low hydraulic conductivity and relatively high recharge) and the relatively steep slope of the surface-water bodies surrounding the contributing area; that is, the headwater streams are several tens of feet higher than the downstream Wolf River near Keshena. These surface-water features have strong control over groundwater-flow directions, and reasonable changes to simulated aquifer properties have only moderate capacity to modify the flow patterns between these surface-water features. Conversely, the areas contributing recharge for other wells, such as the village of Onekewat well (fig. 12), display a diffuse gradation from areas of high probability of capture to low probability of capture. This diffuse gradation in probability is likely a result of the relatively low hydraulic gradient near the well due to the proximity of the well to Legend Lake and other lakes with similar water levels. The sensitivity of hydraulic 

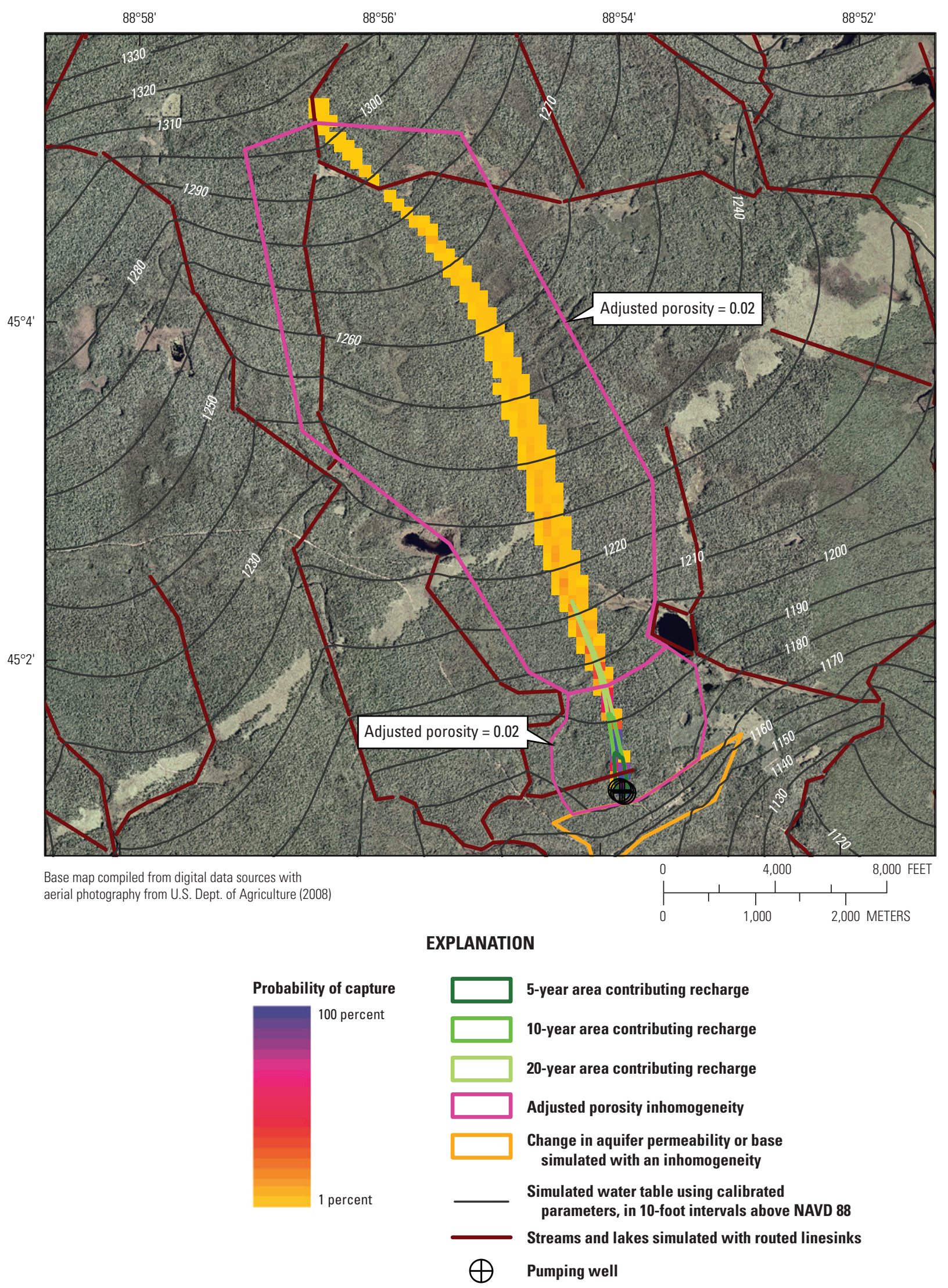

Figure 9. Simulated water-table contours and the area contributing recharge to production wells for the village of Zoar, Menominee Indian Reservation, Wisconsin. Calculations of the adjusted porosity values are described in Table 5 and the "Model Construction and Assumptions" section. 


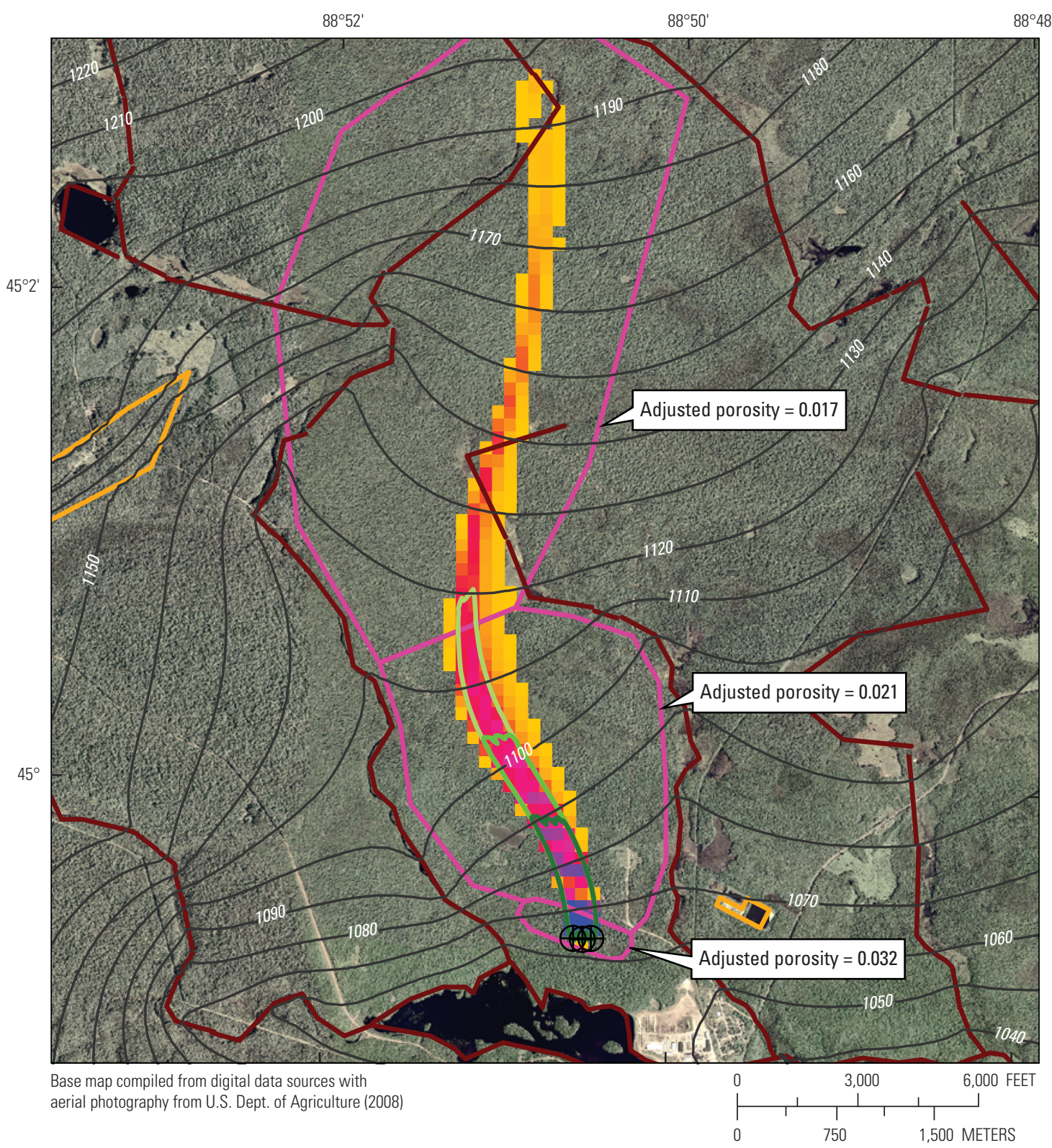

\section{EXPLANATION}

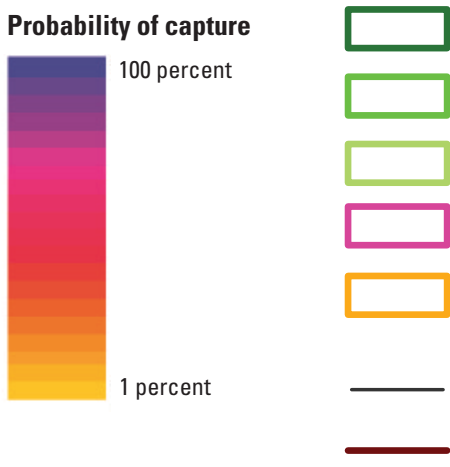

5-year area contributing recharge

10-year area contributing recharge

20-year area contributing recharge

Adjusted porosity inhomogeneity

Change in aquifer permeability or base simulated with an inhomogeneity

Simulated water table using calibrated parameters, in 10-foot intervals above NAVD 88

Streams and lakes simulated with routed linesinks

$\bigoplus \quad$ Pumping well

Figure 10. Simulated water-table contours and the area contributing recharge to production wells for the village of Neopit, Menominee Indian Reservation, Wisconsin. Calculations of the adjusted porosity values are described in Table 5 and the "Model Construction and Assumptions" section. 


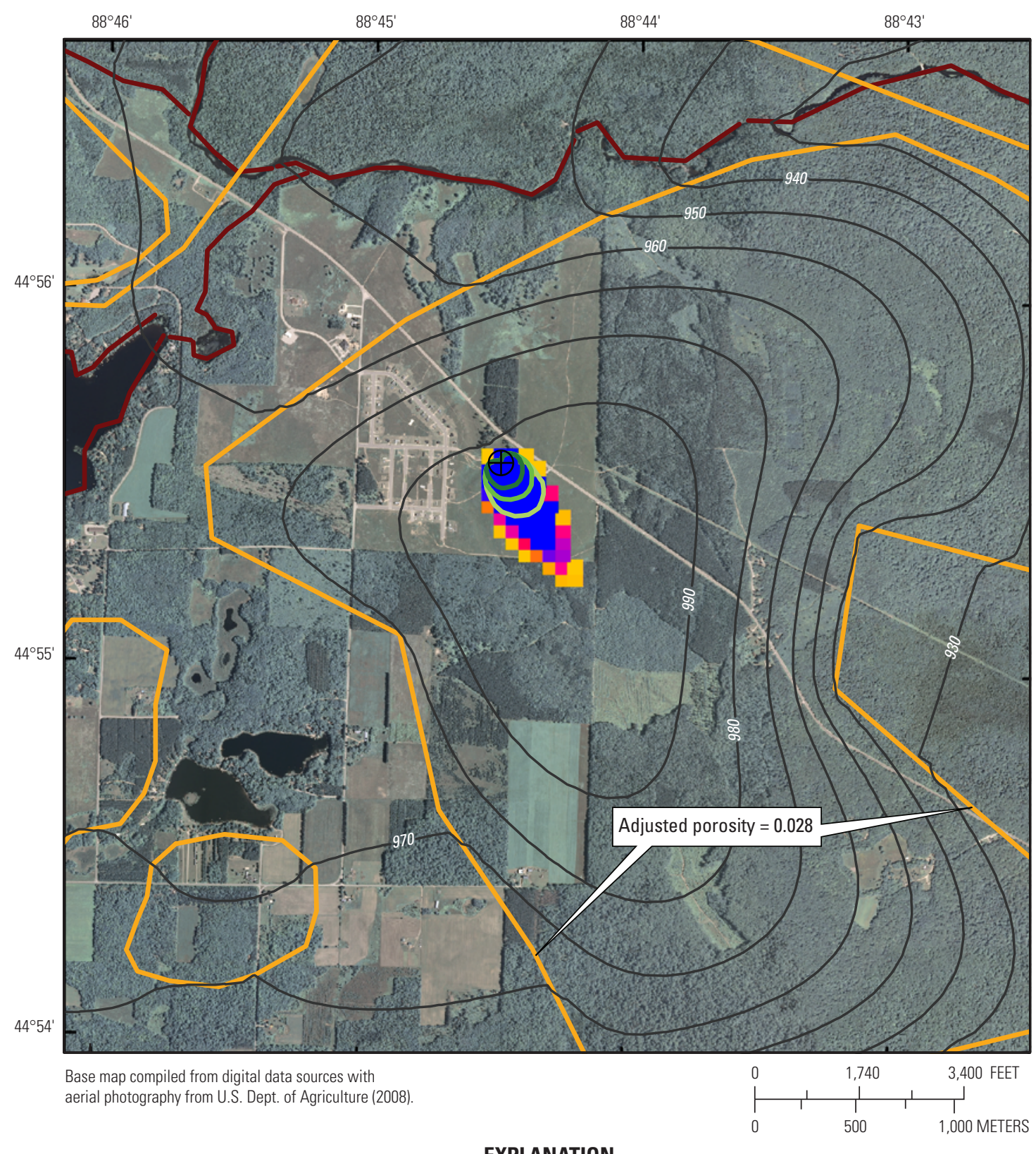

EXPLANATION

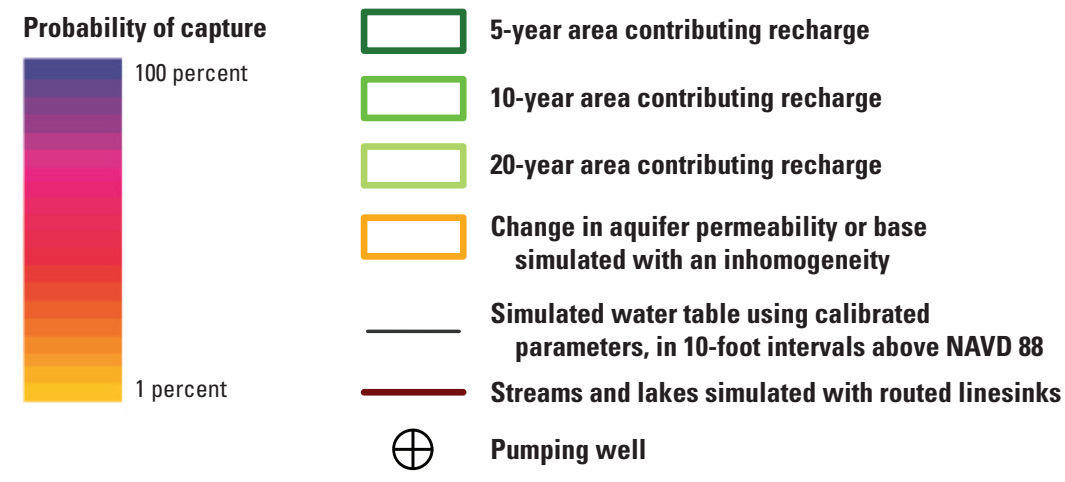

Figure 11. Simulated water-table contours and the area contributing recharge to the production well for Middle Village, Menominee Indian Reservation, Wisconsin. Calculations of the adjusted porosity values are described in Table 5 and the "Model Construction and Assumptions" section. 


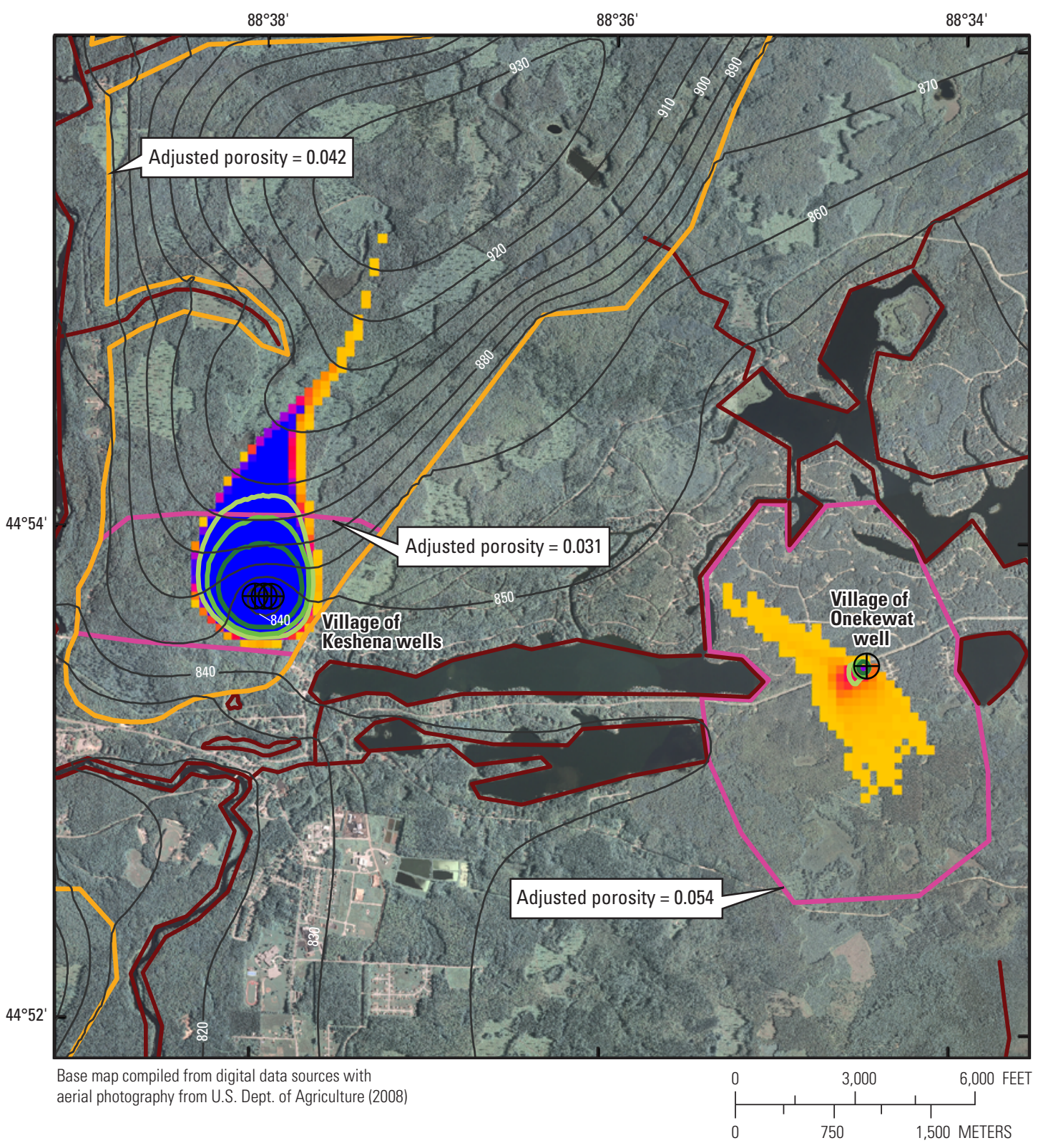

EXPLANATION

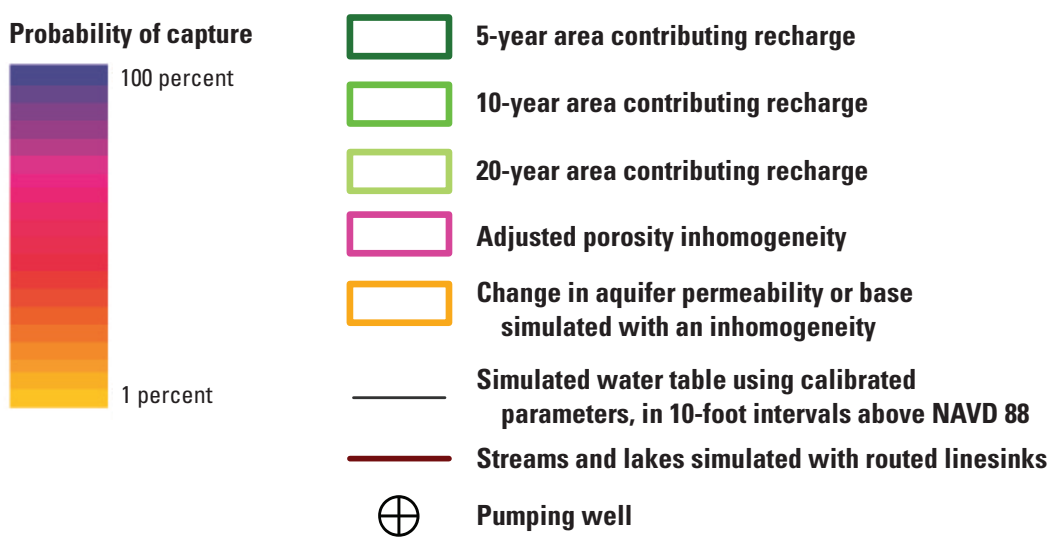

Figure 12. Simulated water-table contours and the area contributing recharge to production wells for the villages of Keshena and Onekewat, Menominee Indian Reservation, Wisconsin. Calculations of the adjusted porosity values are described in Table 5 and the "Model Construction and Assumptions" section. 


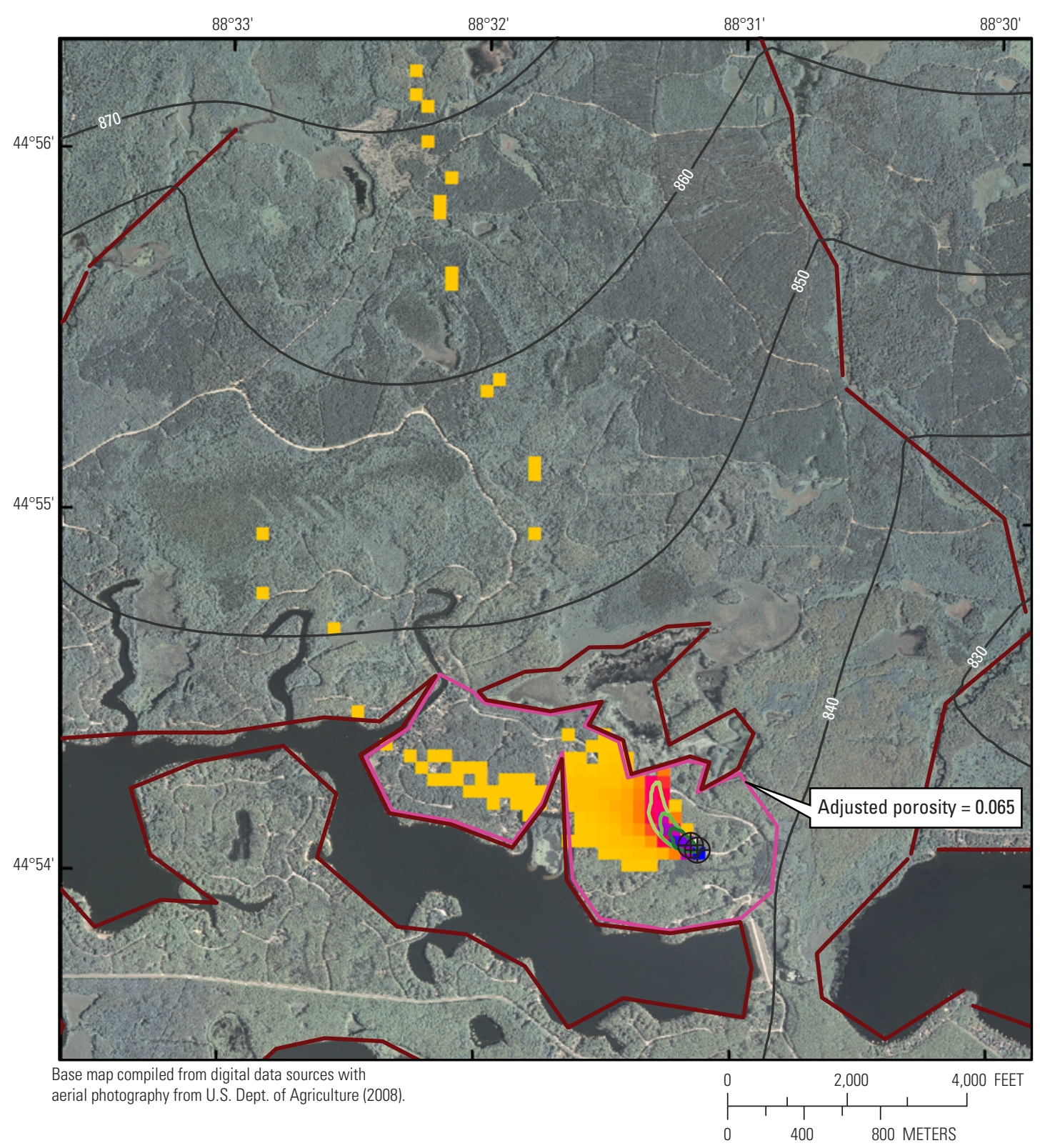

EXPLANATION

Probability of capture

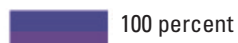

100 percent

1 percent

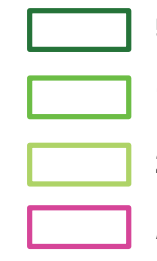

5-year area contributing recharge

10-year area contributing recharge

20-year area contributing recharge

Adjusted porosity inhomogeneity

Simulated water table using calibrated parameters, in 10-foot intervals above NAVD 88

Streams and lakes simulated with routed linesinks

$\bigoplus \quad$ Pumping well

Figure 13. Simulated water-table contours and the area contributing recharge to production wells for the village of Redwing, Menominee Indian Reservation, Wisconsin. Calculations of the adjusted porosity values are described in Table 5 and the "Model Construction and Assumptions" section. 
gradients to small changes in parameter values is most apparent for the Onekewat well (fig. 12) and Redwing wells (fig. 13). For these wells, not only is there a diffuse gradation from high to low probability of capture, but the area with low capture probability is relatively extensive and diffuse.

For the Zoar and Neopit wells, the highest probability of capturing recharge from the water table occurs immediately upgradient of the wells, followed by a narrow band of medium probability extending thousands of feet upgradient (figs. 9 and 10). The distant, low-probability portions of the areas contributing recharge for the Zoar and Neopit wells also intersect a few headwater river linesinks that may contribute a minor amount of water to the wells. It is important to note that the small tributary streams immediately upgradient of the Zoar and Neopit wells were simulated as being dry for the calibrated parameter set and appear to have little influence on the map of probability of capture for the wells. Field reconnaissance to identify whether these headwater streams are perennial may be useful and, if combined with additional local hydrogeologic investigation, could be used to refine representation of the local groundwater-flow system upgradient of the Zoar and Neopit wells.

The probable area contributing recharge to the Middle Village well is concentrated in a small area to the south and east of the well (fig. 11). The relatively small size of the area contributing recharge and the sharp gradient from high to low probability of capture reflects the relatively small distance between the well and a local groundwater mound. The presence of a simulated groundwater mound is supported by target water levels used to calibrate the model. Nonetheless, additional local water-level measurements would be needed to confirm the magnitude and specific location of the mound and, in turn, further reduce uncertainty associated with the area contributing recharge to the Middle Village well.

The probable area contributing recharge to three wells northwest of the village of Keshena is concentrated in a small area north (upgradient) of the wells (fig. 12). Similar to the area contributing recharge to the Middle Village well, this contributing area reflects the relatively small distance between the wells and a local groundwater mound, all of which (the three wells and the mound) are enclosed within a single hydraulic-conductivity zone. Little in the way of calibration data is available to evaluate the extent of the mound, although the natural water bodies and lithologic texture in the area support the simulation of a zone of lower hydraulic conductivity, the simulated flow pattern, and the associated area contributing recharge. Refinement of the local geology through field investigations, in conjunction with refinement of the model, would further reduce uncertainty associated with local areas contributing recharge to wells.

The highest probability of capture for the area contributing recharge to the village of Onekewat well is in the area immediately surrounding the well and extending hundreds of feet to the southwest (fig. 12). An area of relatively lower probability extends to the northwest and southeast of the well. This more diffuse low-probability area is associated with the low pumping rate, which induces a relatively small gradient toward the well that is insufficient to substantially modify the natural hydraulic gradient in the vicinity of the well. Moreover, the difference in water levels among surface-water bodies in the Onekewat area is small, leading to a naturally low water-table gradient that may be sensitive to changes in the model parameters. For example, the lakebed resistance, which controls the hydraulic connection between the aquifer and surrounding lakes, was varied over several orders of magnitude during the Monte Carlo simulation. Order-of-magnitude changes in lakebed resistance can effectively eliminate the lake's influence on the local water table and induce potentially large changes in the local groundwater-flow pattern among individual Monte Carlo realizations. Simulated changes in the local groundwater-flow pattern among realizations are expected to be more pronounced in areas with low water-table gradients compared with high-gradient areas. High uncertainty associated with the riverbed and lakebed resistance parameters is related to the limited information provided by water-level and streamflow targets; that is, investigation of the groundwater/lake-water interaction near Onekewat would be useful for reducing uncertainty associated with local lakebed resistance and, in turn, the area contributing recharge to the well.

The highest probability of capture for the areas contributing recharge to the village of Redwing wells is in the area immediately surrounding the wells and extending hundreds of feet upgradient of the wells toward Long Lake (fig. 13). Areas of relatively lower probability extend to the north and west of the wells. The more diffuse low-probability areas are associated with the naturally low hydraulic gradient in the immediate vicinity of the wells and high uncertainty associated with the lakebed resistance. For example, the low-probability area between Legend and Long Lakes is likely the result of a few realizations for which the lakebed resistance reached values several orders of magnitude greater than the specified value. Direct investigations of groundwater/lake-water interaction near Redwing would be useful for reducing uncertainty associated with local lakebed resistance and the areas contributing recharge to the wells.

\section{Simulation of Flow of Wastewater From Infiltration Lagoons}

The Menominee Tribe and U.S. Indian Health Service recently modified the wastewater-treatment facility for the village of Neopit and are interested in understanding the probable extent of infiltrated wastewater in the downgradient groundwater-flow system. The current operation plans call for rotating wastewater discharge among each of three infiltration lagoons, or seepage cells, on an approximately weekly basis (note that the lagoons were redesigned subsequent to the aerial photograph in fig. 14). Considering the nearly continuous rotation among the infiltration lagoons, the total daily effluent of 86,500 gal/d (Kevin Staus, Indian Health Service, oral commun., 
2013) was distributed among the entire area of the three infiltration lagoons on a steady-state basis in the model. Infiltrated wastewater from the lagoons was simulated using a specified recharge inhomogeneity in the groundwater-flow model.

The horizontal extent of the wastewater plume downgradient from the infiltration lagoons was simulated by using forward particle tracking, with particles tracked from the water table to a terminal surface-water body. The method considered only advective flow from the sources; no attempt was made to evaluate contaminant transport and the various processes that affect it. Instead, results were posed in terms of the probability that one or more particles would flow through a synthetic grid cell in the area downgradient of the lagoons. Monte Carlo techniques were used to estimate the probable horizontal extent of the wastewater plume given a range of parameter values that were informed by covariance matrices from the PEST calibration, in the same manner as was performed to compute probabilistic areas contributing recharge to pumped wells as described previously. The range of model parameter values were sampled by using a Latin Hypercube approach (Starn and Bagtzoglou, 2012) to generate about 800 parameter realizations for the Monte Carlo simulations.

The horizontal extents of the probable wastewater plumes were evaluated according to whether one or more particles passed through individual cells that formed a synthetic grid covering the aquifer in the area of interest. A synthetic grid is required for this plume extent problem because the analysis aims to answer the question, "Does one mathematical particle or more pass through a specific area (as defined by individual grid cells)?" Hence, the entire path of each particle is of interest for this analysis rather than simply an evaluation of whether each particle ultimately arrives at a specific location, such as a pumped well for the areas contributing recharge examples described above. The synthetic grid was constructed with square cells, each $16 \mathrm{ft}$ by $16 \mathrm{ft}$, as guided by the optimized particle-tracking step size estimated by GFLOW for the evaluation window (Haitjema, 1995). One particle was started in each synthetic grid cell (156 particles with 16-ft separation between each particle) over the area occupied by the infiltrating wastewater lagoons and forward tracked through the aquifer until it discharged to a linesink or well.

The method is sensitive to the level of detail used to represent the synthetic grid and the number of particles released from the wastewater source (Juckem and Fienen, 2013). Thus, results for source tracking of the wastewater plume are considered to be qualitative only. Nonetheless, it is expected that the qualitative results will be of use for evaluating management alternatives. For example, areas with extreme probability of capture (values near 100 percent or 1 percent) are expected to be less sensitive to the number of particles and level of discretization than areas with more uncertain probabilities (near 50 percent computed probability). Moreover, this qualitative approach could be used to identify wells or surface-water bodies in areas of concern under simulated hydrologic conditions. For these areas of concern, the problem could be reformulated into an "area contributing recharge" analysis for a well or surface-water body of interest, which is not sensitive to userspecified settings (discretization of synthetic grid or number of tracked water particles).

Wastewater infiltrated from the current wastewater infiltration lagoons flows nearly linearly south from the lagoons toward Tourtillotte Creek and the West Branch Wolf River (fig. 14). Most of the infiltrated wastewater eventually discharges to Tourtillotte Creek. However, some of the infiltrated wastewater is simulated as having a low probability of flowing beneath Tourtillotte Creek and discharging to the West Branch Wolf River. Although results for the probable extent of the wastewater plume are considered to be qualitative, the nearly linear flow pattern is expected to be relatively less sensitive to user-specified settings than the radial flow patterns simulated by Juckem and others (2014).

\section{Assumptions and Limitations}

As is the case with all groundwater-flow models, the GFLOW model of the Menominee Indian Reservation is a simplification of the physical system and has corresponding limitations in model precision and in how the model can be used. For example, local complexities, such as wetlands, springs, and some irregular bedrock topographic features, were not explicitly simulated in the regional model. Although such local features were included if data were available near local areas of interest, such as near some pumped wells, use of the model to answer local-scale questions in other locations would benefit from local refinement, including refinement and (or) addition of linesinks and possibly recalibration of the model with a focus on newly collected local data.

Steady-state conditions were assumed to be appropriate for this system because hydraulic conductivity is high and distances between surface-water features are relatively small; these characteristics help dampen the effects of periodic transient stresses applied to the system (Haitjema, 1995). Steadystate assumptions, which ignore groundwater release from storage, are expected to simulate a greater system response to hydrologic stresses (such as drought or pumping) than transient simulations. In addition, the base of the aquifer system, which corresponds to the crystalline bedrock surface, was specified below mapped elevations in order to improve model performance and solution stability. As a consequence, adjustment of hydraulic-conductivity parameter values was necessary to ensure proper simulation of the bulk transmissivity of the aquifer, groundwater-flow patterns, and groundwater/surface-water interactions. Similarly, simulated porosity values in the model were adjusted upgradient of pumped wells to ensure that simulated groundwater velocities and traveltimes were not biased because of the higher-than-actual saturated thickness employed in the model. 


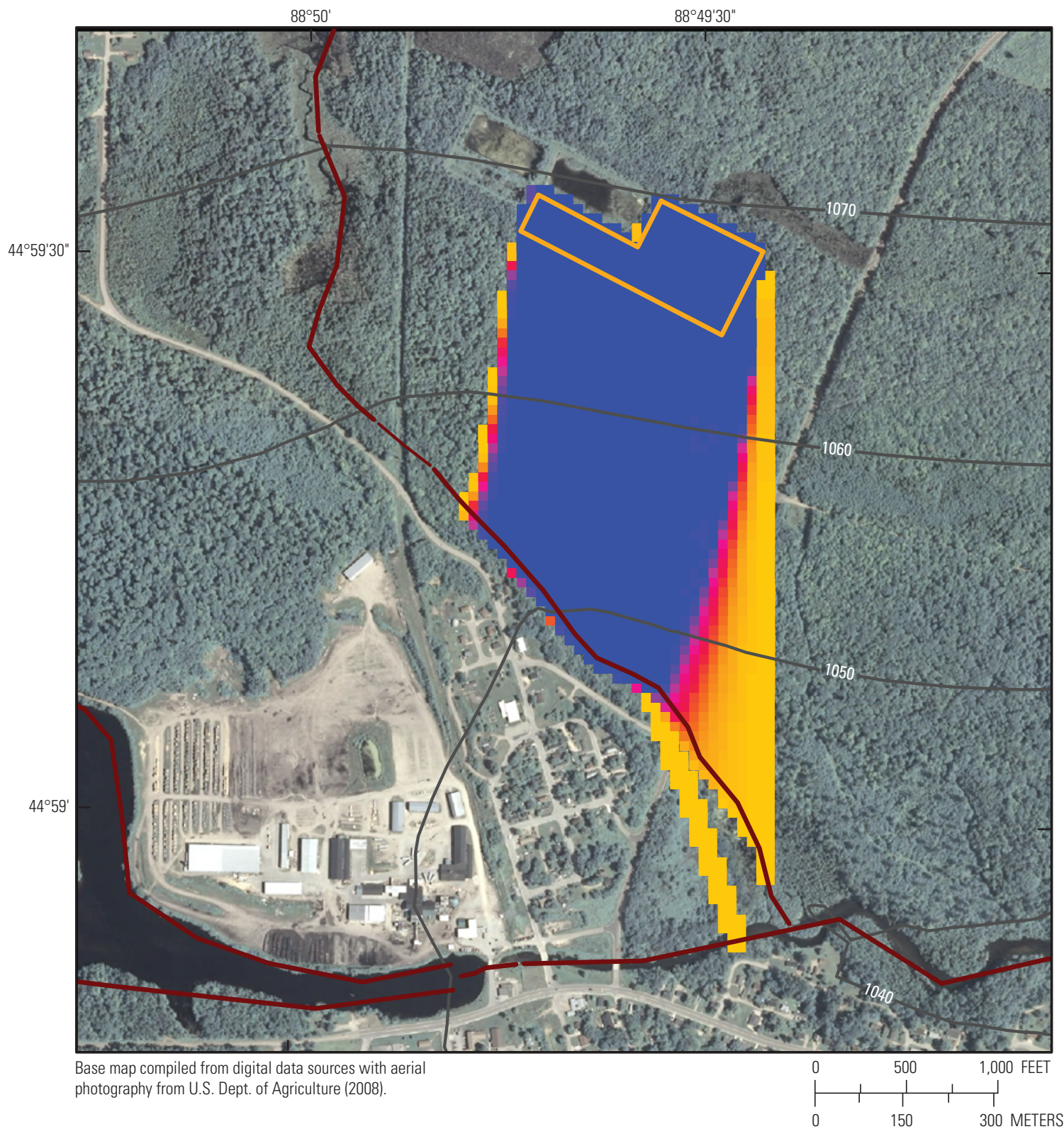

EXPLANATION

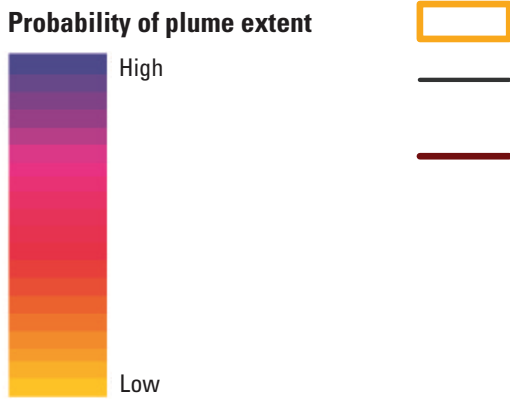

Infiltration lagoon

Simulated water table using calibrated parameters, in 10-foot intervals above NAVD 88

Streams and lakes simulated with routed linesinks

Figure 14. Simulated probability of the horizontal plume extent from the Neopit wastewater-treatment lagoons under current (2013) conditions, Menominee Indian Reservation, Wisconsin. Note that results of this method are considered to be qualitative only. Note also that the wastewater infiltration lagoons were redesigned subsequent to when this aerial photograph was taken. 
Given the relatively high hydraulic conductivity of the aquifer, relatively high groundwater-recharge rate, and presence of perennial streams, the groundwater and surface-water systems are assumed to be in close hydrologic connection in the study area. As a result, elevations of surface-water features are assumed to approximate heads in the underlying groundwater system. An areal two-dimensional groundwater-flow model was assumed to be appropriate for this application because the aquifer is relatively thin (hundreds of feet thick compared to a study area that extends many miles), areally extensive, and assumed to have uniform hydraulic conductivity with depth in each hydraulic-conductivity zone. Limitations of the model arise from these assumptions; specifically, local three-dimensional flow and transient system response expected near wells, infiltration lagoons, and shorelines of surface-water features are not represented. In addition, heterogeneities of the groundwater system (for example, variations in hydraulic conductivity and aquifer base elevation) are only approximated by using zones. These limitations add to the uncertainty associated with estimating areas contributing recharge to wells and mapping wastewater plume extents (Franke and others, 1999). However, the Monte Carlo methods that were employed for this study take uncertainty associated with parameter values partially into account; that is, even though computer modeling always requires simplification of the aquifer system, the use of statistical Monte Carlo methods (or other uncertainty methods) provides a means by which the sensitivity of simulated results to the model input can be tested and visualized (for example, probabilistic areas contributing recharge to pumped wells). Other uncertainties resulting from the model structure were not evaluated (for example, alternative zonations of parameters or alternative conceptual models); therefore, some additional uncertainty in simulated results is expected beyond that presented in this report. Whereas the probabilistic areas contributing recharge are reasonable and supported by observed water-level measurements, focused data collection in combination with local refinement of the model parameters and boundaries could further decrease uncertainty in the simulated areas contributing recharge to wells. In particular, local field investigations of riverbed and lakebed resistance could be useful for reducing uncertainty associated with groundwater/surface-water interaction and could improve simulated areas contributing recharge to wells where surface-water bodies exert strong control over the groundwater-flow system.

Results of Monte Carlo simulations for tracking of wastewater from the infiltration lagoons are sensitive to the number of mathematical water particles (156, each $16 \mathrm{ft}$ apart) used to represent infiltrating wastewater and the level of detail in the synthetic grid (16- by 16-ft-square cells). The resolution of the synthetic grid matched the particle-tracking step size for the simulated area, as computed by GFLOW, and the number of particles represented one particle per synthetic grid cell covering the infiltration lagoons. Although these set-

tings are thought to be reasonable (Juckem and Fienen, 2013), results from the source-water-tracking simulation (fig. 14) are considered qualitative and are to be used with caution for informing management decisions. Moreover, this sourcetracking approach is expected to be most useful for identifying areas of concern downgradient from infiltrated wastewater. A quantitative evaluation of the probability that a well or stream captures wastewater could then be performed for the newly identified areas of concern by use of the "area contributing recharge" method.

\section{Summary and Conclusions}

A regional, one-layer, analytic element groundwaterflow model was developed to simulate the groundwater-flow system in the Menominee Indian Reservation, Wisconsin. The model was developed by the U.S. Geological Survey (USGS), in cooperation with the Menominee Indian Tribe of Wisconsin, to contribute to the fundamental understanding of the region's hydrogeology. The objectives of the regional model were to improve understanding of the groundwater-flow system, including groundwater/surface-water interaction, and to develop a tool suitable for evaluating the effects of potential water-management programs. In addition, the regional model was designed as a framework in which more detail could be added and from which three-dimensional inset models could be developed. Simulations made with the regional model reproduce groundwater levels and stream base flows representative of recent conditions (1970-2013) and illustrate groundwater-flow patterns with maps of (1) the simulated water table and groundwater-flow directions, (2) probabilistic areas contributing recharge to production wells, and (3) estimation of the extent of infiltrated wastewater from treatment lagoons.

The two-dimensional model used for this study was developed with GFLOW, an analytic element groundwaterflow modeling code. The regional aquifer is thin and overlies sloping bedrock, which is problematic for analytic element simulations. To improve model performance, the aquifer base was set below the actual bedrock surface and compensatory hydraulic conductivity and porosity values were used to maintain realistic simulation results. The GFLOW model was calibrated by means of parameter-estimation techniques. During the calibration, hydraulic conductivity and groundwater recharge were adjusted by using the parameter-estimation code PEST to improve the match between simulated and measured water-level and base-flow targets. Sensitivities of calibration targets to parameters were computed by PEST to guide calibration, but such sensitivities do not always identify parameters that are important for prediction scenarios, such as the area contributing recharge to wells. To address this potential inconsistency, Monte Carlo techniques were employed for scenario testing. Parameter covariance matrices computed by PEST during the calibration process were used to guide adjustment of parameters around their calibrated values for about 800 simulations for a given scenario. Maps of the probability for areas contributing recharge to pumped wells were 
then produced by evaluating the percentage of simulations for which an individual modeled particle of water was captured by a well. A map of the probability for the extent of a wastewater plume downgradient of the Neopit wastewater infiltration lagoons was produced by evaluating the percentage of simulations for which one or more modeled particles of wastewater traversed a cell from a synthetic grid placed across the aquifer near the Neopit lagoons.

Major considerations that affect limitations of the model and major findings from the hydrogeologic investigations and groundwater-flow model simulations include the following:

- Zones of uniform hydraulic conductivity and flat aquifer base elevations were used to characterize major glacial sediment deposits and the regional bedrock slope from high elevations in the northwest to low bedrock elevations in the southeastern part of the model. Aquifer base elevations, which correspond to the crystalline bedrock surface, were purposefully specified below the mapped elevations for each zone in order to improve model performance and solution stability. Simulated flow patterns and groundwater/surface-water interactions were appropriately simulated by deriving effective hydraulic conductivities for each zone, which compensated for the exaggerated base elevations. Similarly, groundwater-flow velocities and mathematical particle traveltimes upgradient of pumped wells were appropriately simulated by adjusting porosity values near the wells. Nonetheless, porosity values were not adjusted throughout the model, and any future simulations of groundwater velocity and particle traveltimes beyond the areas contributing recharge to wells would benefit from local porosity adjustment to account for the exaggerated base elevation in the new area of interest.

- Regional groundwater flow generally parallels the regional direction of streamflow. West of the Wolf River, rivers and groundwater generally flow from the northwest toward the southeast. A groundwater divide is present east of the Wolf River, such that groundwater flows west toward the Wolf River and east toward the Oconto River.

- Areas contributing recharge to pumped wells on the Menominee Indian Reservation were delineated by tracking modeled particles of water from the water table to wells in combination with Monte Carlo techniques to produce probability maps for the area contributing recharge to each well nest. The simulations show a range in sensitivity of the simulated areas contributing recharge to the parameters evaluated through the Monte Carlo analysis; that is, areas contributing recharge to some wells show a steep gradation from high to low probability of capture by the pumped well. Such steep gradients imply relative insensitivity to the parameters (hydraulic conductivity, recharge, and lakebed and river bed resistance) that were evaluated through Monte Carlo analysis. Areas contributing recharge to wells that show a diffuse gradient from high to low probability are relatively more sensitive to the model parameters. Factors that influence differences in the shape of contributing areas and the area over which probabilities transition from high to low include (1) the ambient water-table gradient, as controlled by the local geology and elevations of local surface-water bodies, (2) the magnitude of pumping and associated gradients toward the well, (3) the distance between the well and a local groundwater divide or mound, and (4) the degree of hydraulic connection between the aquifer and nearby surface water.

- Although the application of Monte Carlo methods provided a means to evaluate a range of reasonable parameter values and map quantitative probabilities, the application cannot evaluate all possible sources of uncertainty associated with modeled results - the method can test only the properties included in the model, such as zones of hydraulic conductivity. To the extent that other potentially important complexities of the natural system were not included in the model, additional uncertainty is inevitable. Further reductions in uncertainty associated with areas contributing recharge to wells may be gained by means of local field investigations of water levels (monitoring wells), hydraulic conductivity (aquifer tests), and groundwater/surface-water interaction that would provide information on expected reasonable ranges for model parameter values and also identify new complexities for incorporation into the model.

- The likely extent of wastewater in the aquifer downgradient of the Neopit wastewater lagoons was simulated by using the groundwater-flow model and Monte Carlo techniques. Wastewater infiltrated from the lagoons flows predominantly south toward Tourtillotte Creek, with low probability that some of the wastewater flows beneath Tourtillotte Creek and discharges to the nearby West Branch Wolf River. Because the method is susceptible to settings specified by the user, results for source tracking of wastewater are considered to be qualitative only. Although results are considered to be qualitative, the nearly linear flow pattern simulated for the probable plume extent is expected to be relatively less sensitive to user settings than simulated plumes that display radial flow patterns. Regardless, it is expected that the results may be useful for identifying potential areas of concern downgradient of the lagoons, which can then be evaluated with quantitative methods in the future. 


\section{References Cited}

Anderson, M.P., and Woessner, W.W., 1992, Applied groundwater modeling-Simulation of flow and advective transport: San Diego, Academic Press, 381 p.

Attig, J.W., and Ham, N.R., 1999, Quaternary geology of northern Oconto County, Wisconsin: Wisconsin Geological and Natural History Survey Bulletin 97, plate 1, scale $1: 100,000$.

Bradbury, K.R., and Rothschild, E.R., 1985, A computer technique for estimating the hydraulic conductivity of aquifers from specific capacity data: Ground Water, v. 23, no. 2 , p. 240-246.

Calver, A., 2001, Riverbed permeabilities-Information from pooled data: Ground Water, v. 39, no. 4, p. 546-553.

Cannon, W.F.; Kress, T.H.; Sutphin, D.M; Morey, G.B.; Meints, Joyce; and Barber-Delach, Robert, 1997, Digital geologic map and mineral deposits of the Lake Superior Region, Minnesota, Wisconsin, Michigan: U.S. Geological Survey Open-File Report 97-455, scale 1:1,000,000, additional GIS data added in 1999, accessed November 3, 2008, at http://pubs.usgs.gov/of/1997/of97-455/.

Dempster, G.R., Jr., comp., 1990 National water information system user's manual; Volume 2, Chapter 3, Automated data processing system: USGS Open-File Report 90-116 [variously paged].

Doherty, J., 2012, PEST — Model-independent parameter estimation user manual (5th ed.) and addendum: Brisbane, Queensland, Australia, Watermark Numerical Computing.

Farrand, W.R., Mickelson, D.M., Cowan, W.R., and Goebel, J.E., 1984, Quaternary geologic map of the Lake Superior 4 degrees $\times 6$ degrees quadrangle, United States and Canada (edited and integrated by Richmond, G.M., and Fullerton, D.S.): U.S. Geological Survey IMAP 1420(NL-16).

Feinstein, D.T., Fienen, M.N., Kennedy, J.L., Buchwald, C.A., and Greenwood, M.M., 2012, Development and application of a groundwater/surface-water flow model using MODFLOW-NWT for the Upper Fox River Basin, southeastern Wisconsin: U.S. Geological Survey Scientific Investigations Report 2012-5108, 124 p.

Franke, O.L., Reilly, T.E., Pollock, D.W., and LaBaugh, J.W., 1999, Estimating areas contributing recharge to wells - Lessons from previous studies: U.S. Geological Survey Circular $1174,14 \mathrm{p}$.

Freeze, R.A., and Cherry, J.A., 1979, Groundwater: Englewood Cliffs, N.J., Prentice-Hall, 604 p.
Gebert, W.A., Walker, J.F., and Kennedy, J.L., 2011, Estimating 1970-99 average annual recharge in Wisconsin using streamflow data: U.S. Geological Survey Open-File Report 2009-1210, 14 p. plus appendixes.

Hadley, D.W., and Pelham, J.H., comps., 1976, Glacial deposits of Wisconsin: Wisconsin Geological and Natural History Survey, Map 10, scale 1:500,000.

Haitjema, H.M., 1995, Analytic element modeling of groundwater: San Diego, Academic Press, 394 p.

Haitjema, H.M., 2005, Modeling lake-groundwater interactions in GFLOW: 13 p., accessed September 20, 2013, at http://www.haitjema.com/documents/ModelinglakegroundwaterinteractionsinGFLOW.pdf.

Hill, M.C, 1998, Methods and guidelines for effective model calibration: U.S. Geological Survey Water-Resources Investigations Report 98-4005, 90 p.

Hooyer, T.S., and Mode, W.N., 2007, Preliminary Quaternary geologic map of the northern Fox River Lowland, Wisconsin: Wisconsin Geological and Natural History Survey Open File Report 2007-05, map scale 1:100,000.

Hunt, R.J., Anderson, M.P., and Kelson, V.A., 1998, Improving a complex finite-difference ground water flow model through the use of an analytic element screening model: Ground Water, v. 36, no. 6, p. 1011-1017.

Hunt, R.J., 2006, Ground water modeling applications using the analytic element method: Ground Water, v. 44, no. 1, p. $5-15$.

Hunt, R.J., Haitjema, H.M., Krohelski, J.T., and Feinstein, D.T., 2003, Simulating ground water-lake interactionsApproaches and insights: Ground Water, v. 41, no. 2, p. 227-237.

Institute of Hydrology, 1980a, Low flow studies-Report No. 1, Research report: Wallingford, Oxon, UK, 21 p.

Institute of Hydrology, 1980b, Low flow studies-Report No. 3, Catchment characteristic estimation manual: Wallingford, Oxon, UK, p. 12-19.

Juckem, P.F., and Fienen, M.N., 2013, Estimating prediction uncertainty with Monte Carlo techniques and analytic elements, in Proceedings of the MODFLOW and More 2013 Conference, Golden, Co.: p. 235-239.

Juckem, P.F., Fienen, M.N., and Hunt, R.J., 2014, Simulation of groundwater flow and interaction of groundwater and surface water on the Lac du Flambeau Reservation, Wisconsin: U.S. Geological Survey Scientific Investigations Report 2014-5020, 34 p., http://dx.doi.org/10.3133/sir20145020. 
Kelson, V.A., Hunt, R.J., and Haitjema, H.M., 2002, Improving a regional model using reduced complexity and parameter estimation: Ground Water, v. 40, no. 2, p. 132-143.

Krohelski, J.T., Kammerer, P.A., and Conlon, T.D., 1994, Water resources of the Menominee Indian Reservation of Wisconsin: U.S. Geological Survey Water-Resources Investigations Report 93-4053, 54 p.

Martin, Lawrence, 1965, The physical geography of Wiscon$\sin (3 \mathrm{~d}$ ed.): Madison, Wis., University of Wisconsin Press, $608 \mathrm{p}$.

Mickelson, D.M., 1986, Glacial and related deposits of Langlade County, Wisconsin: Wisconsin Geological and Natural History Survey Information Circular 52, 30 p.

Midwestern Regional Climate Center, 2013, Climatological data, accessed Aug., 2013 at http://mrcc.sws.uiuc.edu/climate_midwest/historical/temp/wi/471044_tsum.html.

Milfred, C.J., Olson, G.W., and Hole, F.D., 1967, Soil resources and forest ecology of Menominee County, Wisconsin, with chapters by F.P. Baxter and F.G. Goff, W.A. Creed, and Forest Stearns: University of WisconsinExtension, Wisconsin Geologic and Natural History Survey Bulletin 85, Soil Series No. 60, 203 p.

Mudrey, M.G., Jr., Brown, B.A., and Greenberg, J.K., 1982, Bedrock geologic map of Wisconsin: Wisconsin Geological and Natural History Survey State Map 18, scale $1: 1,000,000$.

Oakes, E.L., and Hamilton, L.J., 1973, Water Resources of Wisconsin-Menominee-Oconto-Peshtigo River Basin: U.S. Geological Survey Hydrologic Investigations Atlas HA-470, sheet 1 .

Olcott, P.G., 1968, Water Resources of Wisconsin-Fox-Wolf River Basin: U.S. Geological Survey Hydrologic Investigations Atlas HA-321, sheet 1.
Poeter, E.P., and Hill, M.C., 1997, Inverse models-A necessary next step in ground-water modeling: Ground Water, v. 35 , no. 2 , p. $250-260$.

Starn, J.J., and Bagtzoglou, A.C., 2012, Programs for calibration-based Monte Carlo simulation of recharge areas: Ground Water, v. 50, no. 3, p. 472-476.

U.S. Department of Agriculture, 2008, National Agricultural Imagery Program (NAIP) digital orthorectified images (DOQ), Wisconsin: Accessed Aug 26, 2013, at http://datagateway.nrcs.usda.gov/.

Vogel, J.C., 1967, Investigation of groundwater flow with radiocarbon, in Proceedings, Symposium on isotopes in hydrology, International Atomic Energy Agency, Vienna, November 14-18, 1966: p. 355-369.

Wahl, K.L., and Wahl, T.L., 1995, Determining the flow of Comal Springs at New Braunfels, Texas, in Texas Water '95, San Antonio, Tex., August 16-17, 1995, Proceedings: American Society of Civil Engineers, p. 77-86.

Wisconsin Department of Natural Resources, 2010, Water well data files: CD-ROM.

Wisconsin Department of Natural Resources, 1998, WISCLAND land cover (WLCGW930): Digital data, accessed July, 2013 at http://dnrmaps.wi.gov/imf/imf. jsp?site $=$ webview.

Wisconsin State Climatology Office, 2013, Northeast Wisconsin average annual precipitation (1895-2013), accessed Aug., 2013 at http://www.aos.wisc.edu/ sco/clim-history/ division/graphics/WI-03-precip-annual.gif. 



\section{Appendix 1. Data from auger surveys near the Villages of Neopit, Zoar, and Keshena}



Appendix 1. Data from auger surveys near the Villages of Neopit, Zoar, and Keshena

[ft, feet; m, meters; -, not determined; UTM, Universal Transverse Mercator; NAD27, North American Datum of 1927; BLS, below land surface]

\begin{tabular}{|c|c|c|c|c|c|c|c|c|c|}
\hline $\begin{array}{c}\text { Site } \\
\text { name }\end{array}$ & $\begin{array}{l}\text { Estimated } \\
\text { ground } \\
\text { elevation } \\
\text { (ft) }\end{array}$ & $\begin{array}{l}\text { Depth to } \\
\text { bedrock } \\
\text { (ft) }\end{array}$ & $\begin{array}{c}\text { Estimated } \\
\text { bedrock } \\
\text { elevation } \\
\text { (ft) }\end{array}$ & $\begin{array}{l}\text { Depth to } \\
\text { water } \\
\text { (ft) }\end{array}$ & $\begin{array}{c}\text { Estimated } \\
\text { water } \\
\text { table } \\
\text { elevation } \\
\text { (ft) }\end{array}$ & $\begin{array}{l}\text { Saturated } \\
\text { thickness } \\
\text { (ft) }\end{array}$ & $\begin{array}{c}\text { Easting } \\
\text { (UTM } \\
\text { NAD27, } \\
\text { m) }\end{array}$ & $\begin{array}{c}\text { Northing } \\
\text { (UTM } \\
\text { NAD27, } \\
\text { m) }\end{array}$ & Lithologic description \\
\hline \multicolumn{10}{|c|}{ Village of Neopit } \\
\hline Neopit A & 1100 & 30 & 1070 & 13.8 & 1086.2 & 16.2 & $354,105.20$ & $4,981,777.59$ & $\begin{array}{l}\text { Uniform reddish, medium to coarse sand. Abundant clean and white quartz } \\
\text { grains, common mafic grains. }\end{array}$ \\
\hline Neopit B & 1095 & 5 & 1090 & Dry & - & 0.0 & $355,046.13$ & $4,981,593.87$ & $\begin{array}{l}\text { Uniform reddish, medium to coarse sand. Abundant clean and white quartz } \\
\text { grains, common mafic grains. }\end{array}$ \\
\hline Neopit C & 1095 & 2 & 1093 & Dry & - & 0.0 & $355,791.98$ & $4,981,189.08$ & - \\
\hline Neopit D & 1081 & 32 & 1049 & 6.3 & 1074.7 & 25.7 & $355,114.85$ & $4,983,370.64$ & $\begin{array}{l}\text { Dark brown, medium-grained quartz sand with some silt, clay, and organic } \\
\text { content. }\end{array}$ \\
\hline Neopit E & 1110 & 8 & 1102 & 4.7 & 1105.3 & 3.3 & $353,909.37$ & $4,981,148.54$ & - \\
\hline Neopit F & 1120 & 22 & 1098 & 4.9 & 1115.1 & 17.1 & $353,397.35$ & $4,981,837.16$ & - \\
\hline Neopit G & 1060 & 14 & 1046 & 7.1 & 1052.9 & 6.9 & $357,027.52$ & $4,981,754.78$ & Reddish, medium sand with minor silty clay. \\
\hline Neopit H & 1100 & 14 & 1086 & 9.3 & 1090.7 & 4.7 & $356,811.09$ & $4,982,903.30$ & - \\
\hline Neopit I & 1070 & 18 & 1052 & 8.3 & 1061.7 & 9.7 & $357,607.55$ & $4,982,789.89$ & - \\
\hline Neopit J & 1090 & 14 & 1076 & 8.4 & 1081.6 & 5.6 & $356,239.27$ & $4,983,043.99$ & - \\
\hline Neopit K & 1100 & 19 & 1081 & 8.0 & 1092.0 & 11.0 & $356,410.57$ & $4,984,102.67$ & Reddish-brown, medium sand with minor silt and clay. \\
\hline Neopit L & 1070 & $>80$ & below 990 & 13.0 & 1057.0 & $>67.0$ & $355,136.93$ & $4,982,709.93$ & $\begin{array}{l}\text { Reddish (slightly grayer than typical), medium-grained sand with some silt } \\
\text { and clay. Sandy clay at bottom of hole. }\end{array}$ \\
\hline Neopit M & 1080 & 23 & 1057 & Dry & - & 0.0 & $354,805.07$ & $4,982,893.09$ & Reddish, medium-grained sand with some silt and clay. \\
\hline Neopit N & 1115 & $>60$ & below 1055 & 25.0 & 1090.0 & $>35.0$ & $354,767.70$ & $4,983,191.81$ & $\begin{array}{l}\text { Reddish, medium-grained sand with some silt and clay. } \\
\text { Many cobbles in lower } 5 \text { - } 10 \text { feet, making augering difficult. } \\
\text { Drilling aborted at } 60 \text { feet. }\end{array}$ \\
\hline Neopit O & 1080 & $>75$ & below 1005 & 14.4 & 1065.6 & $>60.6$ & $355,393.94$ & $4,983,644.39$ & Reddish, medium-grained sand with some silt and clay. \\
\hline Neopit P & 1075 & $>75$ & below 1000 & 20.8 & 1054.2 & $>54.2$ & $353,233.80$ & $4,982,753.44$ & - \\
\hline NEO 05 & 1115 & 108 & 1007 & 65.2 & 1049.8 & 42.8 & $355,266.27$ & $4,982,971.73$ & $\begin{array}{l}\text { Moist, reddish-brown sandy and silty clay from } 0 \text { to } 4 \text { feet. Slightly moist, } \\
\text { reddish-brown silty sand from } 4 \text { to } 9 \text { feet. Slightly moist, reddish-brown } \\
\text { silty sand from } 9 \text { to } 14 \text { feet. Dry, brown sand from } 14 \text { to } 44 \text { feet. Based } \\
\text { on penetration rate, driller estimates dry conditions begin at } 16 \text { feet. } \\
\text { Harder drilling at } 40 \text { feet. Dry, brown sand from } 44 \text { to } 94 \text { feet. Change in } \\
\text { penetration rate at } 47 \text { feet interpreted as occasional pebbles. Volume of } \\
\text { returns decreased below } 74 \text { feet. Moist, brown sand from } 94 \text { to } 108 \text { feet. } \\
\text { Difficult drilling from } 94 \text { to } 108 \text { feet interpreted as pebbles and cobbles. } \\
\text { Driller estimates crystalline bedrock at } 108 \text { feet. Sediment on auger bit } \\
\text { and } 1 \text { foot of lead auger is coarse sand and sandy clay or clayey sand at } \\
108 \text { feet. Indication of water on pulled augers at about } 60 \text { feet; very wet } \\
\text { on pulled augers below } 70 \text { feet. }\end{array}$ \\
\hline NEO 06 & 1100 & 51 & 1049 & Dry & - & 0.0 & $355,446.95$ & $4,982,893.76$ & $\begin{array}{l}\text { Moist, reddish-brown clayey soil and sand from } 0 \text { to } 4 \text { feet. Slightly moist, } \\
\text { reddish-brown clayey sand from } 4 \text { to } 19 \text { feet. Nearly dry, reddish-brown } \\
\text { sand with slight amounts of silt and clay from } 19 \text { to } 24 \text { feet. Dry, brown } \\
\text { sand with occasional pebbles from } 24 \text { to } 51 \text { feet. More difficult drilling } \\
\text { in places between } 44 \text { feet and } 51 \text { feet. Auger refusal at } 51 \text { feet inter- } \\
\text { preted as crystalline bedrock at } 51 \text { feet. Augers dry from } 0 \text { to } 51 \text { feet. }\end{array}$ \\
\hline NEO 08 & 1110 & 74 & 1036 & 23.8 & 1086.2 & 50.2 & $354,929.40$ & $4,983,498.11$ & $\begin{array}{l}\text { Dark-brown sand and road gravel from } 0 \text { to } 4 \text { feet. Slightly moist, reddish- } \\
\text { brown silty sand from } 4 \text { to } 14 \text { feet. Slightly moist, light-reddish-brown } \\
\text { silty sand with occasional pebbles from } 14 \text { to } 19 \text { feet. Dry, light-reddish- } \\
\text { brown silty sand with occasional pebbles from } 19 \text { to } 39 \text { feet. Slightly } \\
\text { moist, very light reddish-brown silty sand with occasional pebbles from } \\
39 \text { to } 44 \text { feet. Moist to wet, very light reddish-brown silty sand with oc- } \\
\text { casional pebbles from } 44 \text { to } 69 \text { feet. Also coarsens and lightens in color } \\
\text { with depth and becomes very wet from } 44 \text { to } 69 \text { feet. Wet, silty fine- } \\
\text { grained sand from } 69 \text { to } 74 \text { feet. Driller estimates crystalline bedrock at } \\
74 \text { feet. Sediment on pulled augers at } 74 \text { feet is very wet, sandy silt. }\end{array}$ \\
\hline NEO 09 & 1113 & 25 & 1088 & Dry & - & 0.0 & $354,760.53$ & $4,983,154.18$ & $\begin{array}{l}\text { Moist, reddish-brown silty sand from } 0 \text { to } 9 \text { feet. Slightly moist, reddish- } \\
\text { brown silty sand with occasional pebbles from } 9 \text { to } 14 \text { feet. Dry, reddish- } \\
\text { brown silty sand with many rounded to angular pebbles (up to } 1.5 \text { inches } \\
\text { in diameter) from } 14 \text { to } 19 \text { feet. Dry, light-brown silty sand with many } \\
\text { rounded to angular pebbles (up to } 1.0 \text { inch in diameter) from } 19 \text { to } 25 \\
\text { feet. Driller estimates crystalline bedrock at } 25 \text { feet. }\end{array}$ \\
\hline NEO 10 & 1110 & $>114$ & below 996 & 27.6 & 1082.4 & $>86.4$ & $355,016.14$ & $4,983,240.33$ & $\begin{array}{l}\text { Slightly moist, reddish-brown silty sand from } 0 \text { to } 9 \text { feet. Slightly moist, } \\
\text { reddish-brown silty sand from } 9 \text { to } 19 \text { feet, with some pebbles or cobbles } \\
\text { within the lower part of this interval. Dry, reddish-brown silty sand from } \\
19 \text { to } 29 \text { feet. Dry, reddish-brown silty sand from } 29 \text { to } 39 \text { feet. Dry at } 29 \\
\text { feet, becoming moist by } 39 \text { feet. Moist, reddish-brown silty sand from } \\
39 \text { to } 49 \text { feet. Moist, brown sandy silt from } 49 \text { to } 54 \text { feet. Wet by } 54 \text { feet. } \\
\text { Wet, brown sandy silt from } 54 \text { to } 74 \text { feet. Wet, brown sand from } 74 \text { to } \\
114 \text { feet. Crystalline bedrock was not reached with the available augers. } \\
\text { Sediment on pulled augers is wet sandy silt. }\end{array}$ \\
\hline NEO 11 & 1120 & 77 & 1043 & 26.6 & 1093.4 & 50.4 & $354,731.65$ & $4,983,787.33$ & $\begin{array}{l}\text { Red sand and soil from } 0 \text { to } 14 \text { feet. Red, fine- to medium-grained sand } \\
\text { with some pebbles from } 14 \text { to } 19 \text { feet. Reddish, fine- to medium-grained } \\
\text { sand from } 19 \text { to } 24 \text { feet. Red, fine- to medium-grained sand with rare } \\
\text { small pebbles from } 24 \text { to } 29 \text { feet. Red, fine- to medium-grained sand } \\
\text { from } 29 \text { to } 34 \text { feet, with increasing coarse fraction and rare small } \\
\text { pebbles. Red, fine- to coarse-grained sand from } 34 \text { to } 54 \text { feet with rare } \\
\text { small pebbles. Moist, red, fine- to coarse-grained sand from } 54-59 \text { feet } \\
\text { with increasing coarse fraction and rare small pebbles. Wet, red fine- to } \\
\text { coarse-grained sand from } 59-69 \text { feet with rare small pebbles. Moist, red } \\
\text { fine- to coarse-grained sand from } 69-77 \text { feet with rare small pebbles. } \\
\text { Driller estimates crystalline bedrock at } 77 \text { feet. throughout the hole there } \\
\text { were sections (few feet thick) encountered which caused bumping and } \\
\text { chattering of drilling (interpreted as cobbles) and tight drilling (high } \\
\text { torque assumed to be caused by clay). Sediment on bottom of pulled } \\
\text { augers is wet sand with no substantial clay. }\end{array}$ \\
\hline NEO 12 & 1110 & 19 & 1091 & Dry & - & 0.0 & $354,845.20$ & $4,983,374.55$ & $\begin{array}{l}\text { Red brown fine- to coarse-grained sand from } 0-19 \text { feet. Driller estimates } \\
\text { crystalline bedrock at } 19 \text { feet. }\end{array}$ \\
\hline
\end{tabular}

${ }^{1}$ Locations of NEO 20 and 21 could not be determined from GPS due to tree cover. Location is estimated based on aerial photos and perceived location along dirt road approximately midway between NEO 10 and 09

${ }^{2}$ Ground elevation of B1, B2, and B3 were surveyed by Menominee Indian Tribe of Wisconsin.

${ }^{3}$ Depth to water for B4 is an estimated average over period of record from May 1 to July 30, 2002. 
[ft, feet; m, meters; -, not determined; UTM, Universal Transverse Mercator; NAD27, North American Datum of 1927; BLS, below land surface]

\begin{tabular}{|c|c|c|c|c|c|c|c|c|c|}
\hline $\begin{array}{c}\text { Site } \\
\text { name }\end{array}$ & $\begin{array}{l}\text { Estimated } \\
\text { ground } \\
\text { elevation } \\
\text { (ft) }\end{array}$ & $\begin{array}{l}\text { Depth to } \\
\text { bedrock } \\
\text { (ft) }\end{array}$ & $\begin{array}{c}\text { Estimated } \\
\text { bedrock } \\
\text { elevation } \\
\text { (ft) }\end{array}$ & $\begin{array}{l}\text { Depth to } \\
\text { water } \\
\text { (ft) }\end{array}$ & $\begin{array}{l}\text { Estimated } \\
\text { water } \\
\text { table } \\
\text { elevation } \\
\text { (ft) }\end{array}$ & $\begin{array}{c}\text { Saturated } \\
\text { thickness } \\
\text { (ft) }\end{array}$ & $\begin{array}{c}\text { Easting } \\
\text { (UTM } \\
\text { NAD27, } \\
\text { m) }\end{array}$ & $\begin{array}{c}\text { Northing } \\
\text { (UTM } \\
\text { NAD27, } \\
\text { m) }\end{array}$ & Lithologic description \\
\hline \multicolumn{10}{|c|}{ Village of Neopit-Continued } \\
\hline NEO 13 & 1110 & $>119$ & below 991 & 22.9 & 1087.1 & $>96.1$ & $354,797.67$ & $4,983,303.19$ & $\begin{array}{l}\text { Red brown sandy soil from 0-9 feet with occasional small pebbles. Red } \\
\text { brown fine- to medium-grained sand from 9-14 feet with some organics } \\
\text { and occasional pebbles. Red brown fine- to medium-grained sand from } \\
14-29 \text { feet with occasional larger pebbles. Moist, red brown fine- to } \\
\text { medium-grained sand from } 29-34 \text { feet with occasional larger pebbles. } \\
\text { Moist, red-brown, fine- to medium-grained sand from } 34 \text { to } 69 \text { feet } \\
\text { with minor silt and occasional larger pebbles. Wet, red-brown, fine- to } \\
\text { medium-grained sand from } 69 \text { to } 89 \text { feet with minor silt and occasional } \\
\text { larger pebbles. No auger returns from } 74 \text { to } 79 \text { feet. Wet, red-brown, } \\
\text { fine- to medium-grained sand from } 89 \text { to } 99 \text { feet with minor silt and } \\
\text { occasional larger pebbles. Wet, red-brown, fine- to medium-grained sand } \\
\text { from } 99 \text { to } 109 \text { feet with minor silt and occasional larger pebbles. Wet, } \\
\text { red-brown, fine- to medium-grained sand from } 109 \text { tol19 feet with some } \\
\text { coarser sand fractions and slight amounts of silt. Crystalline bedrock was } \\
\text { not reached with the available augers. Sediment on auger bit and pulled } \\
\text { augers is wet silty sand with no substantial clay. }\end{array}$ \\
\hline NEO $20^{1}$ & 1100 & 38 & 1062 & Dry & - & 0.0 & $354,903.95$ & $4,983,192.61$ & - \\
\hline NEO $21^{1}$ & 1100 & 19 & 1081 & Dry & - & 0.0 & $354,903.95$ & $4,983,192.61$ & - \\
\hline $\mathrm{B} 1^{2}$ & 1117.6 & 20 & 1097.6 & 14.4 & 1103.2 & 5.6 & $356,280.19$ & $4,983,285.36$ & - \\
\hline $\mathrm{B} 2^{2}$ & 1096.3 & 8 & 1088.3 & 4.8 & 1091.5 & 3.2 & $355,761.16$ & $4,983,491.58$ & - \\
\hline$B 3^{2}$ & 1065.1 & 11 & 1054.1 & 6.3 & 1058.8 & 4.7 & $355,917.25$ & $4,983,034.58$ & - \\
\hline $\begin{array}{l}\text { B4 }^{3} \\
\quad \text { (Neopit } \\
\text { MW 1) }\end{array}$ & 1055 & 45 & 1010 & 13.6 & 1041.4 & 31.4 & $355,861.00$ & $4,982,813.56$ & - \\
\hline
\end{tabular}

\begin{tabular}{|c|c|c|c|c|c|c|c|}
\hline \multicolumn{8}{|c|}{ Village of Zoar } \\
\hline $\begin{array}{l}\text { Zoar } \\
\text { Auger A }\end{array}$ & - & 68 & - & 26.5 & - & 41.5 & $\begin{array}{l}\text { Reddish-brown sand with some silt and clay. Difficulty in bringing augers } \\
\text { to surface interpreted by driller as indication of rock or gravel in sedi- } \\
\text { ments. }\end{array}$ \\
\hline
\end{tabular}

\begin{tabular}{lcccccc} 
Zoar \\
$\quad$ Auger B & - & 43 & - & 8.5 & - & 34.5 \\
$\begin{array}{l}\text { Zoar } \\
\text { Auger C }\end{array}$ & - & $>76$ & - & 25.8 & - & $>50.2$ \\
$\begin{array}{l}\text { Zoar } \\
\text { Auger D }\end{array}$ & - & 26 & - & 5.6 & - & 20.4 \\
\hline
\end{tabular}

ments.

0-4.5 feet, soil; $4.5-10$ feet, uniform fine sand; $10-25$ feet, fine to medium sand; $25-75$ feet, silty sand.

Sand the entire depth.

\begin{tabular}{|c|c|c|c|c|c|c|c|c|}
\hline \multirow[b]{2}{*}{ KE 2} & \multirow[b]{2}{*}{910} & \multirow[b]{2}{*}{72} & \multirow[b]{2}{*}{838} & \multirow[b]{2}{*}{40.9} & \multicolumn{4}{|c|}{ Village of Keshena } \\
\hline & & & & & 869.1 & 31.1 & 370,199 & $4,972,430$ \\
\hline KE 3 & 860 & $>125$ & below 735 & 23.9 & 836.1 & $>101.1$ & 370,518 & $4,971,530$ \\
\hline
\end{tabular}

Thin soil, uniform red-brown sand from surface to about 65 feet. Presence of some cobbles or gravel between 15 and 20 feet suggested by auger behavior. Clayey sand recovered from lead auger at 72 feet.

Thin, dry soil, then clean, brown sand with few fines. Slightly darker brown sand with slightly more silt from 15 to 20 feet BLS. Silty sand with significantly more fines from 20 to 30 feet BLS. Sandy and clayey silt from 30 to 50 feet BLS. Uniform light brown sandy clayey silt from 50 to 70 feet BLS. Slightly coarser silty sand from 70 to 75 feet BLS. Uniform silty clayey saturated sand from 75 to 125 feet BLS. Augers packed with brown clay from 115 to 125 feet BLS.

\begin{tabular}{|c|c|c|c|c|c|c|c|c|c|}
\hline KE 4 & 940 & $>125$ & below 815 & 70.0 & 870.0 & $>55.0$ & 370,710 & $4,972,500$ & $\begin{array}{l}\text { Thin soil, red-brown clayey and silty sand from } 10 \text { to } 30 \text { feet BLS. Transi- } \\
\text { tion from abundant pebbles (angular to rounded) to light-brown, clean, } \\
\text { dry sand with sugary texture from } 30 \text { to } 35 \text { feet BLS. Increase in silt \& } \\
\text { clay from } 100 \text { to } 115 \text { feet BLS. Increase in silt \& clay from } 115 \text { to } 120 \\
\text { feet BLS. }\end{array}$ \\
\hline KE 5 & 940 & $>100$ & below 840 & 87.1 & 852.9 & $>12.9$ & 370,707 & $4,972,230$ & $\begin{array}{l}\text { Thin soil and reddish-brown sand from } 0 \text { to } 5 \text { feet BLS. Transition to sandy, } \\
\text { silty red-brown clay from } 5 \text { to } 10 \text { feet BLS. Sandy, silty red-brown clay } \\
\text { from } 10 \text { to } 20 \text { feet BLS. Very little returns from } 20 \text { to } 40 \text { feet BLS. } \\
\text { Light-brown, sugary sand from } 40 \text { to } 100 \text { feet BLS. }\end{array}$ \\
\hline
\end{tabular}

\begin{tabular}{|c|c|c|c|c|c|c|c|c|c|}
\hline KE 6 & 883 & $>125$ & below 758 & 26.8 & 856.2 & $>98.2$ & 370,815 & $4,971,790$ & $\begin{array}{l}\text { Thin soil with some pebbles and sand from } 0 \text { to } 5 \text { feet BLS. Uniform light- } \\
\text { brown sand with sugary texture and occasional coarse grains from } 5 \text { to } \\
35 \text { feet BLS. Sand as above but darker in color from } 35 \text { to } 70 \text { feet BLS. } \\
\text { Gravelly zone at about } 70 \text { feet. Fine to coarse, light-brown sand and } \\
\text { some silt, with coarse fraction increasing with depth from } 70 \text { to } 80 \text { feet } \\
\text { BLS. Poorly sorted, fine to very coarse sand from } 80 \text { to } 124 \text { feet BLS. } \\
\text { Abundant angular bedrock grains, considerable silt fraction, medium- } \\
\text { brown color from } 124 \text { to } 134 \text { feet BLS. }\end{array}$ \\
\hline KE 7 & 845 & $>130$ & below 715 & 19.1 & 825.9 & $>110.9$ & 370,850 & $4,971,520$ & $\begin{array}{l}\text { No soil. Uniform red-brown sand from } 0 \text { to } 110 \text { feet BLS. Uniform red- } \\
\text { brown sand, some cobbles and gravel, with increasing mafic grains and } \\
\text { silt and clay content with depth from } 110 \text { to } 130 \text { feet BLS. }\end{array}$ \\
\hline KE 8 & 950 & $>125$ & below 825 & 75.0 & 875.0 & $>55.0$ & & & $\begin{array}{l}\text { Red-brown clayey sand with abundant pebbles from } 10 \text { to } 15 \text { feet BLS. } \\
\text { Clean sand (little clay, fewer pebbles) from } 15 \text { to } 20 \text { feet BLS. Clean, } \\
\text { dry, brown sand from } 20 \text { to } 30 \text { feet BLS. Few returns from } 30 \text { to } 35 \text { feet } \\
\text { BLS. Uniform clean, light-brown sand from } 40 \text { to } 125 \text { feet BLS. }\end{array}$ \\
\hline KE 9 & 930 & $>100$ & below 830 & 43.4 & 886.6 & $>56.6$ & 370,722 & $4,972,840$ & $\begin{array}{l}\text { Thin, red, clayey soil from } 0 \text { to } 5 \text { feet BLS. Light-brown, clean, sugary } \\
\text { sand from } 5 \text { to } 50 \text { feet BLS. Transition to darker brown silty sand with } \\
\text { some clay from } 50 \text { to } 60 \text { feet BLS. Auger returns diminished and then } \\
\text { essentially stopped from } 70 \text { to } 80 \text { feet BLS. Few returns, but occasional } \\
\text { pebbles up to } 1 \text { inch from } 80 \text { to } 85 \text { feet BLS. }\end{array}$ \\
\hline KE 12 & 930 & $>125$ & below 805 & 76.7 & 853.3 & $>48.3$ & 370,263 & $4,972,000$ & Thin soil, uniform light-brown sand from 0 to 125 feet BLS. \\
\hline
\end{tabular}

${ }^{1}$ Locations of NEO 20 and 21 could not be determined from GPS due to tree cover. Location is estimated based on aerial photos and perceived location along dirt road approximately midway between NEO 10 and 09 .

${ }^{2}$ Ground elevation of B1, B2, and B3 were surveyed by Menominee Indian Tribe of Wisconsin.

${ }^{3}$ Depth to water for B4 is an estimated average over period of record from May 1 to July 30, 2002. 
For more information concerning the research in this report contact the

Director, Wisconsin Water Science Center

U.S. Geological Survey

8505 Research Way

Middleton, Wisconsin 53562-3586

http://wi.water.usgs.gov/ 


\section{递}

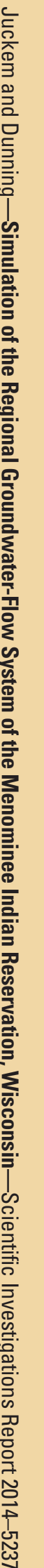

